\title{
REVIEW
}

Open Access

\section{The impact of tropical land-use change on downstream riverine and estuarine water properties and biogeochemical cycles: a review}

Yasuaki Tanaka* (D), Elizerberth Minggat and Wardina Roseli

\begin{abstract}
Tropical primary forests have been disappearing quickly to make use of the land for commercial purposes. Land-use change has an impact on downstream aquatic processes, but those impacts have mainly been studied in temperate climate regions. The present article reviews the impacts of various tropical land-use changes caused by human activities on downstream riverine and estuarine water properties and biogeochemical cycles, focusing especially on the behaviors of nitrogen $(\mathrm{N})$ and phosphorus $(\mathrm{P})$. Logging of tropical primary forests, subsequent establishment of pasture lands, and occasional wildfire or intentional burning have decreased terrestrial $\mathrm{N}$ fixation and increased the discharge of P combined with soils, which has lowered the N:P ratio of dissolved inorganic nutrients in the adjacent stream waters and downstream rivers. Agricultural fertilizers and aquacultural practices basically cause nutrient enrichment in downstream riverine and estuarine waters, changing the N:P ratio depending on the source. Finally, urbanization causes eutrophication in many tropical estuaries, where a halocline forms easily because of a warm temperature throughout the year and the water at the bottom of the estuary tends to become hypoxic or anoxic. Overall, the impact of land-use change on aquatic processes may be more serious in tropical regions than in temperate or cold climate regions because of (1) a higher biomass and nutrient stock in original tropical forests; (2) higher precipitation, more frequent episodic flooding, and warmer temperatures in tropical regions; and (3) certain practices that are rapidly expanding in tropical regions such as land-based aquaculture. Various land-use changes are causing downstream nutrient enrichment or disturbance of the nutrient balance at tropical land-sea interfaces, and the overall N:P ratios in the aquatic ecosystem seem to be declining. Nonetheless, if proper management is conducted and the discharge of nutrients and soils ceases, tropical aquatic systems may have the potential to recover faster than those in other climate regions because of their abundant precipitation and warm temperature. Long-term monitoring and more attention to elemental stoichiometry are important areas for future research.
\end{abstract}

Keywords: Deforestation, Land-use change, Eutrophication, Water quality, Hypoxia, Environmental monitoring, Aquatic conservation, Water resources

* Correspondence: yasuaki.tanaka@ubd.edu.bn

Environmental and Life Sciences, Faculty of Science, Universiti Brunei

Darussalam, Jalan Tungku Link, Gadong BE1410, Brunei Darussalam

\section{Springer Open}

(- The Author(s). 2021 Open Access This article is licensed under a Creative Commons Attribution 4.0 International License, which permits use, sharing, adaptation, distribution and reproduction in any medium or format, as long as you give appropriate credit to the original author(s) and the source, provide a link to the Creative Commons licence, and indicate if changes were made. The images or other third party material in this article are included in the article's Creative Commons licence, unless indicated otherwise in a credit line to the material. If material is not included in the article's Creative Commons licence and your intended use is not permitted by statutory regulation or exceeds the permitted use, you will need to obtain permission directly from the copyright holder. To view a copy of this licence, visit http://creativecommons.org/licenses/by/4.0/. 


\section{Introduction}

Primary forests have been globally cut down with increasing human populations and expanding commercial land use; in particular, tropical forests have been lost faster than those in other climate regions during the past several decades (Gibbs et al. 2010; Miettinen et al. 2011; Achard et al. 2014; Rosa et al. 2016). As a result, for example, the eastern lowlands of Sumatra and the peatlands of Borneo lost approximately half of their peat swamps for conversion to industrial plantations from 2000 to 2010 (Miettinen et al. 2011), and the Brazilian Amazon lost $15 \%$ of the primary forest by 2010 (Maia and Schons 2020). Not only inland forests but also coastal forests have been cut down quickly. Tropical coasts and estuaries are often bordered by mangrove forests, but it was estimated that $35 \%$ of global mangroves were already lost from 1980 to 2000 (Valiela et al. 2001), although recently the rate seems to be declining (Friess et al. 2019). At the global level, the gross loss of tropical forests has been estimated to be 8 million ha per year from 1990 to 2010 (0.5\% annually; Achard et al. 2014). These deforested lands have been replaced with commercial lands for various purposes: agricultural fields (e.g., rice, soybeans, and oil palm), aquaculture ponds, or ranching and poultry farms, depending on the demands of the region (Chen et al. 2013; Richards and Friess 2016).

Generally, tropical forests and their soil have higher carbon $(\mathrm{C})$ and nitrogen $(\mathrm{N})$ stocks than those in other climate regions because of active photosynthesis and biological $\mathrm{N}$ fixation throughout the year (Cleveland et al. 1999; Jobbágy and Jackson, 2000; Hedin et al. 2009; Cloern et al. 2014). Organic litter is fragmented into dissolved and particulate organic matter (DOM and POM, respectively) and is mineralized into carbon dioxide $\left(\mathrm{CO}_{2}\right)$ by bacteria faster in the tropics because of warmer temperatures (Wetterstedt et al. 2010). When precipitation and throughfall pass through forest soils, the concentration of dissolved organic carbon (DOC) in the soil solution gradually declines with soil depth because DOC tends to be adsorbed to soil particles (McDowell 1998). Because of organic matter decomposition, the ammonium $\left(\mathrm{NH}_{4}{ }^{+}\right)$concentration is relatively high in the surface soil but is gradually oxidized into nitrate $\left(\mathrm{NO}_{3}{ }^{-}\right)$as soil water moves downstream as groundwater (McDowell et al. 1995; McDowell 1998). Phosphate $\left(\mathrm{PO}_{4}{ }^{3-}\right)$ is also regenerated from organic matter decomposition, but $\mathrm{PO}_{4}{ }^{3-}$ tends to be adsorbed to soil and does not percolate deeply into groundwater (McDowell et al. 1995; McDowell 1998). Thus, stream waters surrounded by tropical primary forest and its downstream river and estuarine waters are usually enriched with dissolved inorganic carbon (DIC) and $\mathrm{NO}_{3}{ }^{-}$(McDowell 1998; Miyajima et al. 2009; Brookshire et al. 2012; Noriega and
Araujo 2014). DIC and $\mathrm{N}$ exports from undisturbed tropical watersheds are generally higher than those from temperate watersheds because of the higher stock of organic matter and active bacterial mineralization in the forest (Hedin et al. 2009; Sarma et al. 2011; Abril et al. 2014). However, along with the disappearance of tropical primary forests, less organic matter is produced on land, and more organic matter is discharged downstream by increased erosion, which results in a reduction in the stock of soil organic C and N (Brown and Lugo 1990; Brouwer and Riezebos, 1998; Don et al. 2011; Drake et al. 2019; Hattori et al. 2019). Therefore, the impact of deforestation on downstream limnological processes is expected to be greater in tropical regions than in other climate regions.

Conversely, artificial nutrient loading, such as the application of fertilizers, increases with human land use after deforestation because many human activities involve the use of nutrients (Downing et al. 1999). In agriculture, more than half of applied fertilizers are often not recovered by plants but can accumulate in soils, volatilize to the atmosphere, or leach from the land to ambient streams and rivers through groundwater or surface water runoff (Rocha et al. 2019). The impact of fertilizers may remain in the soil even after several decades (Sebilo et al. 2013). The fluxes of total $\mathrm{N}(\mathrm{TN})$ or $\mathrm{NO}_{3}{ }^{-}$ in rivers are correlated with population densities in the watershed, and TN fluxes have increased by 2- to 20fold in temperate rivers since industrialization (Howarth et al. 1996), although the trend is specific to the catchment and is also highly affected by climatic drivers, such as hydrology and temperature (Argerich et al. 2013). The discharge of total phosphorus (TP) and $\mathrm{PO}_{4}{ }^{3-}$ has also been increasing with wastewater discharge, artificial drainage systems, and erosion (Nieminen et al. 2017; Williams and King 2020). Because tropical regions often experience more rainfall than other climate regions, more $\mathrm{N}$ and phosphorus (P) might be discharged with water from tropical lands.

The impacts of land-use change on downstream aquatic processes have mainly been studied in temperate regions, and some reviews are available (Howarth et al. 2011; Statham 2012; Bauer et al. 2013). However, reviews of the impacts on tropical regions are scarce (Downing et al. 1999; Camara et al. 2019; Thomaz et al. 2020), even though the impacts are expected to be different from those seen in other climate regions, as introduced above. To summarize our present understanding of changing tropical aquatic processes, the present article reviews the impacts of various tropical land-use changes on the water properties and biogeochemical cycles in adjacent streams, rivers, and estuaries. We focused on six major land-use changes: (1) logging of primary forests, (2) pasture including ranching, (3) 
agriculture, (4) forest fire including intentional burning, (5) aquaculture, and (6) urbanization affected by various types of wastewaters. We collected published literature mainly from Google Scholar and focused on studies that directly compared water properties or biogeochemical cycles between sites affected or unaffected by land-use change. In the present review, tropical regions were defined as the warmest areas in the Köppen-Geiger climate classification (roughly between $20^{\circ} \mathrm{N}$ and $20^{\circ} \mathrm{S}$; Peel et al. 2007).

\section{Logging}

Tropical land-use change starts from deforestation by logging primary forests. At this stage, both above- and belowground plant biomasses are drastically and quickly removed from the land, where the soil is dug up and loosened. Subsequent transportation of timber by tractors further disturbs the ground, which causes runoff of surface water and soils downstream after rainfall (Nykvist et al. 1996; Chappell et al. 2004). Moreover, total evaporation (or evapotranspiration) from the land may be reduced due to less vegetation, and more rainwater flows into the adjacent streams and rivers after logging (Chappell et al. 2005; Ling et al. 2016). The groundwater baseflow also increases because of the reduced uptake of infiltrated rainwater by terrestrial plants. In the Bukit Berembun catchments in Peninsular Malaysia, the average water yield increased by $50-70 \%$ after commercial logging (Nik and Harding 1992; Chappell et al. 2005). The increased volume and velocity of water flows erode stream banks, making the stream increasingly wider (Iwata et al. 2003; Neill et al. 2006).
Most previous studies on the effects of logging on downstream riverine water properties have focused on the monitoring of suspended solids (SS) or turbidity, and increases in these water variables have been recorded at many study sites during and after logging (Table 1). The increase in SS and turbidity is mainly caused by soils, but dissolved inorganic nutrients (e.g., $\mathrm{NO}_{3}{ }^{-}$and $\mathrm{PO}_{4}{ }^{3-}$ ), minerals (e.g., $\mathrm{K}^{+}, \mathrm{Mg}^{2+}$, and $\mathrm{Ca}^{2+}$ ), and organic matter are also discharged from soils (Table 1). Because terrestrial plant-derived organic matter generally has a higher $\mathrm{C}: \mathrm{N}$ ratio than aquatic microbes in rivers, the discharge of terrestrial organic matter from logging sites increases the C:N ratio of total organic matter in the river (Ward et al. 2015; Zhang et al. 2019). In the Changhuajiang River basin, China, the C:N ratio of POM increased from 7 to 10 during the wet season, where more terrestrial particles were discharged downstream due to high precipitation and strong soil erosion (Zhang et al. 2019). In addition, the N:P ratio of tropical plant leaves is occasionally very high due to the active $\mathrm{N}$ fixation of the forest ecosystem compared to temperate or cold climate regions (Hedin et al. 2009). This finding suggests that the $\mathrm{N}: \mathrm{P}$ ratio of $\mathrm{POM}$ in the downstream river might be higher in tropical regions than expected in other climate regions.

River water $\mathrm{pH}$ can also be altered due to terrestrial inputs because most soils in the humid tropics are acidic (e.g., $\mathrm{pH}=4.5-6.4$; Grip et al. 2005). This acidity has both biological and chemical causes: microbial processes (e.g., aerobic oxidation, methanogenesis, sulfate reduction, nitrification) enrich the soil pore water with $\mathrm{H}^{+}$ and various forms of oxidized $\mathrm{C}$ and $\mathrm{N}$ (e.g., $\mathrm{CO}_{2}, \mathrm{CH}_{4}$, $\mathrm{NO}_{3}{ }^{-}$) (Melling et al. 2005; Ríos-Villamizar et al. 2017),

Table $1 \mathrm{~A}$ summary of the effects of logging on the downstream riverine and estuarine water properties. The arrows indicate that the subsequent water properties increased $(\uparrow)$, decreased $(\downarrow)$, or did not change $(\rightarrow)$. See the list of abbreviations for water properties

\begin{tabular}{|c|c|c|}
\hline Study sites & $\begin{array}{l}\text { Effects on downstream water } \\
\text { properties }\end{array}$ & Sources \\
\hline Bukit Berembun rivers, Negri Sembilan, Malaysia & $\uparrow: \mathrm{SS}$, turbidity, $\mathrm{NO}_{3}{ }^{-}, \mathrm{PO}_{4}{ }^{3-}$ & Chappell et al. (2004, 2005) \\
\hline Bukit Tarek streams, Selangor, Malaysia & $\uparrow:$ EC, SS, turbidity & Gomi et al. (2006), Marryanna et al. (2007) \\
\hline Danum Valley rivers, Sabah, Malaysia & $\uparrow: S S$ & $\begin{array}{l}\text { Douglas et al. (1992), Greer et al. (1996), Nainar } \\
\text { et al. (2017) }\end{array}$ \\
\hline Mendolong catchment, Sabah, Malaysia & $\begin{array}{l}\uparrow: \mathrm{EC}, \mathrm{TN}, \mathrm{NO}_{3}{ }^{-}, \mathrm{NH}_{4}^{+}, \mathrm{DOC} \\
\downarrow: \mathrm{DOC}: \mathrm{DON}\end{array}$ & Malmer and Grip (1994) \\
\hline Baleh River, Sarawak, Malaysia & $\begin{array}{l}\uparrow: \mathrm{pH}, \mathrm{SS}, \mathrm{DO} \\
\rightarrow: \mathrm{TP}^{-} \\
\downarrow: \mathrm{NO}_{3}{ }^{-}, \mathrm{PO}_{4}{ }^{3-}, \mathrm{Chl} . a\end{array}$ & Ling et al. (2016) \\
\hline Batam River, Sarawak, Malaysia & $\uparrow:$ SS, turbidity & Ling et al. (2017) \\
\hline Rivers, Seram, Indonesia & $\uparrow:$ SS & Cecil et al. (2003) \\
\hline Bongan River, East Kalimantan, Indonesia & $\uparrow:$ SS & de Jong et al. (2015) \\
\hline $\begin{array}{l}\text { Bukit Baka Experimental Catchment, Central Kalimantan, } \\
\text { Indonesia }\end{array}$ & $\uparrow:$ SS & Suryatmojo et al. (2014) \\
\hline Purus river, Amazonas, Brazil & $\downarrow: \mathrm{pH}$ & Ríos-Villamizar et al. (2017) \\
\hline
\end{tabular}


and weathering of parent material may also directly acidify adjacent aquatic systems by reacting with precipitation or moisture. For example, acid sulfate soil (ASS) is widely distributed in tropical regions and is stable under anoxic conditions. However, when ASS is exposed to oxygen (atmosphere) with water, which is often driven by logging during a rainy season, ASS starts to be oxidized, producing $\mathrm{H}^{+}$and causing severe acidification of the downstream rivers (Sammut et al. 1996; Vuai et al. 2003; Van Ha et al. 2011). In the Kahayan River in Central Kalimantan, Indonesia, the surface water $\mathrm{pH}$ dropped to as low as 3 due to ASS during a rainy season (Haraguchi 2007).

Because P combines with certain soil minerals (e.g., calcium, iron, and aluminum), enhanced soil runoff due to logging would involve a drastic transportation of $\mathrm{P}$ from the surface land to the downstream aquatic ecosystem, decreasing the N:P ratio (Chappell et al. 2005). In the downstream estuary, suspended particulate $\mathrm{P}$ desorbs from the soil particles, and $\mathrm{PO}_{4}{ }^{3-}$ becomes available for primary producers (Zhang and Huang 2011; Lin et al. 2012; Nguyen et al. 2019a). The sorption/desorption of $\mathrm{P}$ is chemically affected by the water temperature and salinity; $\mathrm{PO}_{4}{ }^{3-}$ desorption is enhanced with decreasing temperature or increasing salinity (Zhang and Huang 2011). However, in a turbid tropical estuary of Saigon, Vietnam, the SS concentration was the greatest factor in determining the $\mathrm{P}$ content in the water because of the high flocculation of cohesive sediments (Nguyen et al. 2019a). These properties of $P$ indicate the importance of the management of soil discharge from logging sites to prevent $\mathrm{P}$ overloading in downstream aquatic ecosystems. All the above types of runoff (i.e., water, soil, organic matter, and nutrients) would be alleviated by riparian vegetation because the vegetation zone functions as a filter (Williams et al. 1997; Gomi et al. 2006; de Souza et al. 2013).

The effects of logging on downstream riverine and estuarine water could last for months to years until the terrestrial soil is gradually stabilized and plants regrow naturally or artificially. During the recovery period, the discharge of $\mathrm{N}$ and $\mathrm{P}$ into the adjacent river seems to return to the original level before logging earlier than other mineral ions (e.g., $\mathrm{K}^{+}, \mathrm{Ca}^{2+}, \mathrm{Mg}^{2+}$ ) (Malmer and Grip 1994; Chappell et al. 2005). For example, in the rivers of the Mendolong catchment, Malaysia, the concentration of $\mathrm{NO}_{3}{ }^{-}$returned to the original level within 2 years after clear felling, but the $\mathrm{K}^{+}$concentration was still high even after 5 years (Malmer and Grip 1994). This difference suggests that $\mathrm{N}$ and $\mathrm{P}$ often limit the growth of terrestrial vegetation after logging and thus are subject to active absorption by the vegetation for regrowth, while other minerals, such as $\mathrm{K}^{+}$, are relatively sufficient for plants because they are continuously leached from soil and rock through weathering (Malmer and Grip 1994; McDowell 1998; Chappell et al. 2005). However, from a longer-term viewpoint, the removal of terrestrial vegetation and the gradual erosion of soils decrease the storage of nutrients and minerals on land (Recha et al. 2012; Hattori et al. 2019), which would eventually lower the concentration of these ions in the downstream river and estuarine water.

To summarize this section, logging increases the discharge of terrestrial soils, including nutrients and organic matter that are stored in the forest (Table 2). Because tropical forest soils store larger biomass stocks than those of other climate regions, the impact of logging on organic matter and nutrient discharge would be greater in tropical regions, especially when episodic heavy rainfall occurs. The discharge of soils might increase the $\mathrm{C}: \mathrm{N}$ ratio of organic matter and decrease the $\mathrm{N}: \mathrm{P}$ ratio of dissolved inorganic nutrients in the downstream river and estuary (Table 2). The increase in turbidity caused by soil and organic matter might reduce aquatic photosynthesis in the downstream river and estuary, but in contrast, the discharged nutrients have the potential to increase productivity. The final productivity would be determined by the balance of these effects.

\section{Pastures and ranches}

After deforestation, the land is often changed to pasture by natural sprouts or seedings of a target species of grass. The grown pasture may be repeatedly burned to remove unwanted weeds and used for ranches (Neill et al. 2001, 2017). If fertilizers are not added to pasture lands, nutrient stocks in the soil may gradually decline from the original stock in primary forests (Hattori et al. 2019; López-Poma et al. 2020). Because of deforestation and conversion to pasture, the primary production and standing stock of biomass are decreasing globally on tropical lands (Erb et al. 2016). Ranching of aviculture, swine, and cattle for livestock production is the major use of pasture lands, especially in Latin America. Brazil alone accounts for almost half of the livestock

Table 2 A summary of the common effects of tropical landuse change on the downstream riverine and estuarine water properties. The arrows indicate that the water properties would increase $(\uparrow)$, decrease $(\downarrow)$, or not change $(\rightarrow)$. See the list of abbreviations for water properties

\begin{tabular}{lllllll}
\hline Land use & SS & TN & TP & OC:ON & TN:TP & DO \\
\hline Logging & $\uparrow$ & $\uparrow$ & $\uparrow$ & $\uparrow$ & $\downarrow$ & $\downarrow$ \\
Pasture and ranching & $\uparrow$ & $\uparrow \downarrow$ & $\uparrow$ & $\downarrow$ & $\downarrow$ & $\downarrow$ \\
Agriculture & $\uparrow$ & $\uparrow$ & $\uparrow$ & $\downarrow$ & $\uparrow \downarrow$ & $\downarrow$ \\
Burning & $\uparrow$ & $\uparrow$ & $\uparrow$ & $\uparrow$ & $\uparrow \downarrow$ & $\downarrow$ \\
Aquaculture & $\uparrow \downarrow$ & $\uparrow$ & $\uparrow \downarrow$ & $\downarrow$ & $\uparrow \downarrow$ & $\rightarrow$ \\
Urbanization & $\uparrow$ & $\uparrow$ & $\uparrow$ & $\downarrow$ & $\downarrow$ & $\downarrow$ \\
\hline
\end{tabular}


production in Latin America and the Caribbean (OECD/ FAO 2019).

Because of its extensive area and long history, the impacts of the conversion of tropical primary forest to pasture on adjacent stream waters have been frequently studied in the Amazon region (de Mello et al. 2020; Thomaz et al. 2020; Table 3). In the Amazonian state of Rondônia, Brazil, forest reserves were logged from 1987 to 1990 and were mostly planted with Brachiaria grass species for extensive cattle ranching (Thomas et al. 2004; Nóbrega et al. 2018). The planted grasses had low productivity compared to the primary forest (Nóbrega et al. 2018). Due to the conversion from primary forest to grasses, decreased canopy densities allowed more sunlight to reach streams, which increased the temperature and primary production in the stream water (Thomas et al. 2004; Lorion and Kennedy 2009). Most of the measured organic and nutrient contents in the stream waters were higher alongside pastures than the streams surrounded by primary forest during the dry season, although the difference was smaller or negligible during the wet season because of the dilution by rainwater (Biggs et al. 2004; Neill et al. 2006; Thomas et al. 2004; Deegan et al. 2011; Nóbrega et al. 2018). Higher POM and DOM would be derived from aquatic vegetation, which became dominant on the stream banks in pastures due to increased light availability (Neill et al. 2001; Nóbrega et al. 2018). $\mathrm{NH}_{4}{ }^{+}$ and $\mathrm{PO}_{4}{ }^{3-}$ also increased through the mineralization of the organic matter produced by aquatic vegetation in the stream, which led to lower dissolved oxygen (DO) in the water (Thomas et al. 2004).

Conversely, $\mathrm{NO}_{3}{ }^{-}$may decrease in the pasture streams because less $\mathrm{N}$ fixation, mineralization, and nitrification could occur on the pasture lands than in the original primary forest (Neill et al. 2001; Thomas et al. 2004; Table 3). The reduced $\mathrm{NO}_{3}{ }^{-}$concentration lowered the $\mathrm{N}: \mathrm{P}$ ratio of dissolved inorganic nutrients in the stream waters of the Amazon regions, shifting from a P limitation in forest streams to an $\mathrm{N}$ limitation in pasture streams for aquatic primary producers (Neill et al. 2001; Figueiredo et al. 2020). A similar reduction in N:P ratios in stream waters was also observed in pasturedominated watersheds in Panama (Valiela et al. 2013). Because tropical primary forests have high $\mathrm{N}$ fixation and provide excess N downstream (McDowell 1998; Hedin et al. 2009; Brookshire et al. 2012), this reduction in $\mathrm{NO}_{3}{ }^{-}$and the $\mathrm{N}: \mathrm{P}$ ratio would be more impactful in tropical regions than in other climate regions. The total fluxes of these nutrients would be greatly affected by water discharge, and therefore, long-term monitoring is important to observe seasonal changes and to assess annual budgets (Williams et al., 1997; Nóbrega et al. 2018).

Pasture lands are often used for ranching to raise livestock animals. The grazing of grass by those animals

Table 3 A summary of the effects of the conversion of primary forest to pastures and ranches on the downstream riverine and estuarine water properties. The arrows before the water properties indicate that the subsequent water properties increased $(\uparrow)$, decreased $(\downarrow)$, or did not change $(\rightarrow)$. See the list of abbreviations for the water properties

\begin{tabular}{|c|c|c|}
\hline Study sites & Effects on downstream water properties & Sources \\
\hline Rayu River, Sarawak, Malaysia & $\rightarrow: \mathrm{pH}_{1} \mathrm{NO}_{3}{ }^{-}, \mathrm{NO}_{2}^{-}, \mathrm{NH}_{4}^{+}, \mathrm{PO}_{4}{ }^{3-}$ & Iwata et al. (2003) \\
\hline Rivers, Queensland, Australia & $\uparrow: \mathrm{PON}, \mathrm{NO}_{3}^{-}$ & Furnas (2003) \\
\hline \multirow[t]{5}{*}{ Rondônia, Amazon Basin, Brazil } & $\uparrow: T D N, T D P, P P$ & Biggs et al. (2004) \\
\hline & $\begin{array}{l}\uparrow: \mathrm{SS}_{1} \mathrm{POC}, \mathrm{PON}, \mathrm{DON}, \mathrm{PO}_{4}{ }^{3-} \\
\rightarrow: \mathrm{TDN}^{-} \mathrm{NH}_{4}^{+} \\
\downarrow: \mathrm{NO}_{3}{ }^{-}, \mathrm{TDN}: \mathrm{TDP}, \mathrm{DIN}: \mathrm{DIP}, \mathrm{DO}\end{array}$ & Neill et al. (2001) \\
\hline & $\begin{array}{l}\uparrow: \mathrm{SS}_{1} \mathrm{POC}, \mathrm{PON}, \mathrm{NH}_{4}{ }^{+}, \mathrm{PO}_{4}{ }^{3-}, \mathrm{Chl} a \\
\downarrow: \mathrm{NO}_{3}{ }^{-}, \mathrm{DO}\end{array}$ & Thomas et al. (2004) \\
\hline & $\downarrow: \mathrm{NO}_{3}{ }^{-}, \mathrm{DIN}: \mathrm{DIP}, \mathrm{DO}$ & Neill et al. (2006) \\
\hline & $\begin{array}{l}\uparrow: \mathrm{SS}_{1} \mathrm{NH}_{4}^{+}, \mathrm{PO}_{4}^{3-} \\
\downarrow: \mathrm{NO}_{3}{ }^{-}, \mathrm{DIN}: \mathrm{DIP}, \mathrm{DO}\end{array}$ & Deegan et al. (2011) \\
\hline Paragominas streams, Pará, Brazil & $\begin{array}{l}\uparrow: \mathrm{pH}_{1} \mathrm{DO} \\
\downarrow: \mathrm{NO}_{3}^{-}\end{array}$ & Figueiredo et al. (2010) \\
\hline Novo Progresso (Amazon) and Campo Verde (Cerrado), Brazil & $\uparrow: \mathrm{TOC}, \mathrm{DOC}, \mathrm{TN}, \mathrm{NO}_{3}^{-}$ & Nóbrega et al. (2018) \\
\hline Sarapuí River Basin, São Paulo, Brazil & $\begin{array}{l}\uparrow: \text { SS, turbidity, TP } \\
\rightarrow: \text { TN }\end{array}$ & de Mello et al. (2018a) \\
\hline Sixaola River streams, Limón, Costa Rica & $\uparrow:$ Chl $a$ & Lorion and Kennedy (2009) \\
\hline Veraguas rivers and estuaries, Panama & $\begin{array}{l}\uparrow: \mathrm{SS}_{\mathrm{C}} \mathrm{Chl} a \\
\rightarrow: \mathrm{PO}_{4}{ }^{3-} \\
\downarrow: \mathrm{NO}_{3}^{-}, \mathrm{NH}_{4}^{+}, \mathrm{DIN}: \mathrm{DIP}\end{array}$ & Valiela et al. $(2013,2014)$ \\
\hline Streams, Puerto Rico & $\begin{array}{l}\uparrow: \text { Turbidity, TN, TP } \\
\rightarrow: \text { DO }\end{array}$ & Uriarte et al. (2011) \\
\hline
\end{tabular}


generally enhances (1) the cycling of plant decomposition and nutrient regeneration through digestion and excretion by animals (Assmann et al. 2017; Arnuti et al. 2020) and (2) soil erosion from fragile stream banks (McCulloch et al. 2003; Brodie and Mitchell 2005). Dung nutrients are recycled by terrestrial plants or utilized as manure fertilizer for agriculture (Sileshi et al. 2017), but some of them can flow into adjacent streams with precipitation. In the Amazon catchment, the fluxes of total inorganic C (TIC) and TN increased by 5 and 3.7 times, respectively, in the streams surrounded by pasture lands with extensive cattle ranching compared to those in primary forests (Nóbrega et al. 2018). This increase in TIC was caused by the practice of liming $\left(\mathrm{CaCO}_{3}\right)$ in the pasture to raise the $\mathrm{pH}$ of the indigenous acidic soils. A meta-analysis of the chemical composition of animal manure from sub-Saharan countries showed that $77 \%$ of manure had N:P ratios less than 5, which is lower than the N:P requirement of major crops (Sileshi et al. 2017). When plants take up available nutrients, the N:P ratio of the residue would decrease further. The accumulation of $\mathrm{P}$ relative to $\mathrm{N}$ was also found in subtropical pastures with livestock grazing in Florida, USA (Ho et al. 2018). The discharge of these P-rich residues into streams may shift the limitation factor from $\mathrm{P}$ to $\mathrm{N}$ for primary production in downstream aquatic ecosystems (Jennerjahn et al. 2008; see "Agriculture").

If deforested lands or pasture lands are abandoned, they will gradually regenerate trees by natural seeding or artificial plantations as secondary forests. Generally, it takes a longer time for tropical lands to recover their floral and faunal diversity than temperate lands because of the higher diversity in the original tropical forest (Meli et al. 2017). In the Rayu River catchment of Borneo, Malaysia, slash-and-burn agricultural practices were performed until 1989, but then the area was protected as a national park, and a secondary forest was redeveloped. In 1998, the dissolved inorganic nutrients, electrical conductivity (EC), and $\mathrm{pH}$ in the stream water of the secondary forest were no longer different from those of the original primary forest (Iwata et al. 2003). However, the stream substrates were finer and the banks were more eroded in the secondary forest, most likely because of the loss of the riparian primary forest during the initial deforestation. Because of this physical alteration of habitats, the diversity and abundance of aquatic organisms (e.g., periphyton, aquatic insects, shrimp, and fish) were still lower in the streams surrounded by the secondary forest than in those surrounded by the primary forest (Inoue et al. 2003; Iwata et al. 2003). These observations suggest that even if secondary forest develops, the recovery of aquatic habitats and ecosystems would take a longer time than that of chemical water properties (Feio et al. 2015).
To summarize this section, the conversion of primary forest to pasture lands enables more sunlight to reach the ground and adjacent lotic ecosystems, increasing the temperature and primary production in the water. Because terrestrial $\mathrm{N}$ fixation declines with deforestation, the $\mathrm{NO}_{3}{ }^{-}$concentration and the $\mathrm{N}: \mathrm{P}$ ratio of dissolved inorganic nutrients in the downstream riverine and estuarine waters would decrease (Table 2), and this reduction would be more drastic in tropical regions than in other climate regions. Ranching further decreases the $\mathrm{N}$ : $P$ ratio in the water due to the input of animal excretion. Both aquatic primary production and the input of animal excretion increase DOM and POM in downstream rivers and estuaries, causing high turbidity and low DO in the water (Table 2).

\section{Agriculture}

Primary forests are frequently converted to lands for agriculture in tropical regions. The net agricultural production in Southeast Asia has increased by approximately 3\% per year over the past several decades (OECD/FAO 2017). In Southeast Asia, rice cultivation was the main agricultural activity until the 1980s, but the percentage of rice production to the total agricultural production has been decreasing for the past 40 years; instead, palm oil and poultry production are increasing because of the higher income they generate (OECD/FAO 2017). In Latin America and the Caribbean, soybeans are the major agricultural products, and their production has increased fourfold during the past 40 years (OECD/FAO 2019). As seen in logging and pasture lands, agricultural lands also cause increased runoff of surface water and soil. In the Nandi district, Kenya, the water runoff increased twofold after the primary forest was converted to croplands (Recha et al. 2012).

In agricultural fields, synthetic fertilizers, which are commonly composed of soluble inorganic nutrients (e.g., ammonium chloride, diammonium phosphate, potassium chloride) or organic nutrients that decompose rapidly, such as urea, are frequently used, although natural organic fertilizer (e.g., animal manure and vegetable compost) has recently received attention (Ding et al. 2019). Synthetic fertilizers are created to quickly dissolve and be efficiently absorbed by crop plants, but in general, only $10-50 \%$ of applied $\mathrm{N}$ and $\mathrm{P}$ fertilizers are recovered as crop harvests (Prasertsak et al. 2002; Chen et al. 2008; Ding et al. 2019). The remaining N percolates through soil into groundwater, discharges with surface water runoff, or it is released into the atmosphere through volatilization (e.g., $\mathrm{NH}_{3}$ ) or denitrification (e.g., $\mathrm{N}_{2}$ and $\mathrm{N}_{2} \mathrm{O}$ ) (Downing et al. 1999; Rivett et al. 2008; Maranguit et al. 2017). Conversely, P tends to remain in the surface soil or be discharged with sediment as surface runoff because of its ability to bind to 
certain soil minerals (Faithful and Finlayson 2005; Zhang and Huang 2011; Nguyen et al. 2019a).

In the Brazilian Amazon and Cerrado, the major crops are soybean, maize, corn, and cotton, and the effects of fertilizers on the adjacent stream water quality have been frequently reported (Figueiredo et al. 2010; Silva et al. 2011; Riskin et al. 2017; Neill et al., 2017; Figueiredo et al., 2020; de Mello et al. 2020). After the land use shifted from pasture to agriculture, the concentration of most of the measured nutrients, minerals, and EC increased, while DO decreased in the stream surrounded by agricultural fields with the use of fertilizers (Figueiredo et al. 2010; Silva et al. 2011; de Mello et al. 2018b; Table 4). Even though the concentration appeared to be unaffected, the impact of fertilizer may become obvious when annual export is measured. In the Brazilian state of Mat Grosso, the nutrient concentration in stream waters was not affected by soybean cropping compared to primary forest, but the annual export of nutrients was higher from soybean fields than the forest watershed because of the increased water discharge from the soybean fields (Riskin et al. 2017).

Oil palm plantations are one of the most extensive agricultural crops in the tropics and consume the largest amount of commercial fertilizers in Southeast Asia (Maranguit et al. 2017), but the effects on adjacent streams or rivers have not been well studied (Ah Tung et al. 2009; Comte et al. 2012, 2015; Gandaseca et al. 2015; Table 4). Because of fertilizer use, the rivers surrounded by new oil palm plantations in Sarawak, Malaysia, had higher $\mathrm{NH}_{4}{ }^{+}$and biological and chemical oxygen demands (BOD and COD, respectively) than the controlled forest sites (Gandaseca et al. 2015). The surface runoff from the mature oil palm farms of Papua New Guinea also had higher $\mathrm{NH}_{4}{ }^{+}$concentrations than the controlled sites, and the nutrient and water balance implied that a considerable amount of $\mathrm{N}$ was lost as deep drainage by leaching (Banabas et al. 2008). The groundwater collected from the well in the oil palm plantation of Sabah, Malaysia, had high $\mathrm{NH}_{4}{ }^{+}$and $\mathrm{K}^{+}$ concentrations, which were likely derived from fertilizer (Ah Tung et al. 2009). The $\mathrm{NO}_{3}{ }^{-}$concentration was not significantly affected by fertilizer at these oil palm sites in Southeast Asia, demonstrating that nitrification is not a major process in $\mathrm{N}$ transformation in these agricultural lands. Because of the high precipitation in Southeast Asia, fertilizer-derived $\mathrm{NH}_{4}{ }^{+}$could be discharged into streams and rivers before being oxidized into $\mathrm{NO}_{3}{ }^{-}$. At an oil palm plantation in Sumatra, Indonesia, the use of organic fertilizer caused a high BOD and COD level in the adjacent stream water, which also suggests a short residence time of fertilizer-derived organic matter in the surface soil (Comte et al. 2015).

Conversely, $\mathrm{NO}_{3}{ }^{-}$may become the major fertilizerderived nutrient in regions where precipitation percolates and travels underground as groundwater with a relatively long residence time. In northern Queensland, Australia, sugarcane and banana cultivation have been the major industries over the last century, and the details have been reviewed in several articles (Furnas 2003; Brodie and Mitchell 2005; Davis et al. 2016). In brief, the use of fertilizer in this region increased the $\mathrm{NO}_{3}{ }^{-}$concentration in the groundwater through nitrification (Thorburn et al. 2003), and fertilizer-derived $\mathrm{NO}_{3}{ }^{-}$flowed into adjacent streams and rivers as baseflow (Mitchell et al. 2001, 2009). The N:P ratio of dissolved inorganic nutrients in the Tully River was much higher than the Redfield ratio $(\mathrm{N}: \mathrm{P}=16)$ throughout the year (Faithful and Finlayson 2005), indicating that P limited aquatic primary production in the river. High $\mathrm{N}: \mathrm{P}$ ratios of dissolved inorganic nutrients in groundwaters or river waters affected by agricultural fertilizers have also been reported in many other tropical and subtropical regions, e.g., Hawaii (USA), Java (Indonesia), Okinawa (Japan), and São Paulo (Brazil), where the major $\mathrm{N}$ form is $\mathrm{NO}_{3}{ }^{-}$ (Blanco et al. 2010; Bishop et al. 2017; Taniwaki et al. 2017; Oehler et al. 2018).

The impact of fertilizer would also be different depending on the type of fertilizer: in the Kallada River, India, where a large part of the catchment is dominated by agricultural plantations (e.g., rice, coconut, tea, and rubber), low N:P ratios of dissolved inorganic nutrients were measured in the downstream river region (Jennerjahn et al. 2008). The ratio of $\mathrm{NO}_{3}{ }^{-}$to $\mathrm{PO}_{4}{ }^{3-}$ ranged from 2.9 to 8.0; the lowest value was measured during the wet season. This low N:P ratio seems to have been caused by the use of organic fertilizers such as urea and manure in this region (Jennerjahn et al. 2008). Similar effects are expected to occur by ranching, as mentioned in the above section.

To summarize this section, the effect of agricultural fertilizer on the adjacent stream and river waters is not straightforward but is affected by various factors (e.g., chemical composition and amount of fertilizer, soil properties, precipitation). Simply speaking, if fertilizer-derived nutrients are quickly flushed downstream with rainfall, the $\mathrm{N}: \mathrm{P}$ ratio in the discharged water would be affected by the residue of the fertilizer. In contrast, if fertilizer-derived nutrients remain in the soil or percolate into groundwater with a long residence time, the groundwater would have high $\mathrm{N}: \mathrm{P}$ ratios of dissolved inorganic nutrients because $\mathrm{P}$ tends to be chemically trapped in soils. Considering the climate of tropical regions, the former case could occur more commonly or frequently than in other climate regions. Regardless of which case occurs, downstream primary production would increase due to fertilizer-derived nutrients. 
Table 4 A summary of the effects of agriculture on the downstream riverine and estuarine water properties. When most minerals (e.g., $\mathrm{Na}^{+}, \mathrm{Mg}^{2+}, \mathrm{Cl}^{-}, \mathrm{K}^{+}, \mathrm{Ca}^{2+}$ ) increased, they were collectively described as EC increased. The arrows before the water properties indicate that the subsequent water properties increased $(\uparrow)$, decreased $(\downarrow)$, or did not change $(\rightarrow)$. See the list of abbreviations for the water properties

\begin{tabular}{|c|c|c|}
\hline Study sites & $\begin{array}{l}\text { Effects on downstream water } \\
\text { properties }\end{array}$ & Sources \\
\hline Jambi estuary rivers, Sumatra, Indonesia & $\uparrow: S S, T O C$ & Sanderson and Taylor (2003) \\
\hline Streams at the Petapahan area, Sumatra, Indonesia & $\rightarrow:$ DIN, TP & Comte et al. (2015) \\
\hline Rivers at Sibu and Tatau, Sarawak, Malaysia & $\begin{array}{l}\uparrow: \mathrm{COD}_{1} \mathrm{NH}_{4}^{+} \\
\downarrow: \mathrm{pH}, \mathrm{DO}\end{array}$ & Gandaseca et al. (2015) \\
\hline Rajang River, Sarawak, Malaysia & $\begin{array}{l}\uparrow: \mathrm{SS} \\
\downarrow: \mathrm{pCO}_{2}\end{array}$ & Müller-Dum et al. (2019) \\
\hline Sundar River, Sarawak, Malaysia & $\uparrow: \mathrm{EC}$, turbidity, $\mathrm{NH}_{4}{ }^{+}, \mathrm{COD}$ & Rosli et al. (2020) \\
\hline Groundwater at Tawau, Sabah, Malaysia & $\begin{array}{l}\uparrow: \mathrm{NH}_{4}^{+} \\
\rightarrow: \mathrm{NO}_{3}^{-}\end{array}$ & Ah Tung et al. (2009) \\
\hline Buyhang watershed streams, Leyte, Philippines & $\begin{array}{l}\uparrow: \text { Turbidity } \\
\downarrow: \mathrm{NO}_{3}^{-}, \mathrm{PO}_{4}{ }^{3-}\end{array}$ & Dessie and Bredemeier (2013) \\
\hline Surface runoff at Sangara and Dami, Papua New Guinea & $\begin{array}{l}\uparrow: \mathrm{NH}_{4}^{+} \\
\rightarrow: \mathrm{NO}_{3}^{-}\end{array}$ & Banabas et al. (2008) \\
\hline Tully River, Queensland, Australia & $\begin{array}{l}\uparrow: \mathrm{SS}_{1} \mathrm{PON}, \mathrm{NO}_{3}^{-}, \mathrm{PO}_{4}^{3-} \\
\rightarrow: \text { DON, } \mathrm{PP}, \mathrm{DOP}\end{array}$ & Mitchell et al. (2001), Furnas (2003) \\
\hline $\begin{array}{l}\text { Tully and Murray Rivers, Granite Creek, Queensland, } \\
\text { Australia }\end{array}$ & $\uparrow: S S, T N, T P$ & Faithful and Finlayson (2005) \\
\hline Herbert River, Queensland, Australia & $\uparrow: S S, T N, T P$ & $\begin{array}{l}\text { Bramley and Roth (2002), Mitchell et al. } \\
\text { (1997) }\end{array}$ \\
\hline Cudgen Catchment, New South Wales, Australia & $\begin{array}{l}\uparrow: \mathrm{pH} \\
\downarrow: \mathrm{pCO}_{2}\end{array}$ & Jeffrey et al. (2016) \\
\hline Kallada River and Ashtamudi estuary, Kerala, India & $\begin{array}{l}\uparrow: \mathrm{SS}_{1} \mathrm{NO}_{3}^{-}, \mathrm{PO}_{4}^{3-} \\
\downarrow: \mathrm{DIN}: \mathrm{DIP}\end{array}$ & Jennerjahn et al. (2008) \\
\hline Nawuni Catchment, Ghana & $\uparrow:$ Turbidity, $\mathrm{NH}_{4}^{+}$ & Tahiru et al. (2020) \\
\hline Federal District streams, Brasilia, Brazil & $\begin{array}{l}\uparrow: \mathrm{EC}_{1} \mathrm{NO}_{3}{ }^{-}, \mathrm{NO}_{2}^{-}, \mathrm{NH}_{4}^{+} \\
\rightarrow: \mathrm{DON}, \mathrm{PO}_{4}{ }^{3-} \\
\downarrow: \mathrm{DO}\end{array}$ & Silva et al. (2011) \\
\hline Tanguro Ranch, Mat Gross, Brazil & $\uparrow: \mathrm{EC}, \mathrm{SS}, \mathrm{DOC}, \mathrm{NH}_{4}^{+}, \mathrm{PO}_{4}{ }^{3-}$ & Riskin et al. (2017) \\
\hline Paragominas streams, Pará, Brazil & $\begin{array}{l}\uparrow: \mathrm{EC}, \mathrm{pH}, \text { turbidity, } \mathrm{NO}_{3}{ }^{-} \\
\rightarrow: \mathrm{PO}_{4}^{3-} \\
\downarrow: \mathrm{DO}\end{array}$ & Figueiredo et al. (2010) \\
\hline Sarapuí River Basin, São Paulo, Brazil & $\uparrow:$ SS, turbidity, POM, TN, TP & De Mello et al. (2018a, b) \\
\hline Streams, Puerto Rico & $\uparrow: D O, T P$ & Uriarte et al. (2011) \\
\hline
\end{tabular}

\section{Wildfire and intentional burning}

Humid tropical forests are generally resistant to burning, but the transition from primary to secondary forests, shrubs, pastures, and agricultural plantations increases the frequency of fires (da Silva et al. 2018; Adrianto et al. 2020). Not only natural wildfires but also intentional burning to remove weeds for agriculture may trigger extensive fires. In Southeast Asia, $50 \%$ of forests were affected by fire from 2003 to 2017 (Reddy et al. 2019). The area of forest fires increased 36-fold in the Amazon region from 1984 to 2016 (da Silva et al. 2018). Forest fires provoke airborne release and deposition of suspended matter and gaseous chemicals, causing extensive haze in tropical regions (Tacconi 2016).
The effects of forest wildfire or intentional burning on the adjacent stream and river water quality have been studied well in temperate regions, such as North America, but they have not been frequently studied in tropical regions (Earl and Blinn 2003; Smith et al. 2011; Rust et al. 2018). Basically, terrestrial organic matter is combusted into ash, black carbon, or volatized chemicals, which are released into the atmosphere or transported into the adjacent aquatic ecosystem. The composition and amount of ash or black carbon (including both organic and inorganic matter) change with the temperature and duration of burning: a higher combustion completeness decreases the organic matter content and increases the relative content of minerals (Audry 
et al. 2014; Bodí et al. 2014). Because ash is easily discharged from burnt forests with surface water runoff after rainfall (Malmer and Grip 1994; Ice et al. 2004; Dittmar et al. 2012), episodic, heavy rainfall that frequently occurs in tropical regions could cause a more rapid loss of nutrients and organic matter from the land compared with temperate regions (Marques et al. 2017).

In the Mendolong catchments of northern Borneo, Malaysia, the effects of the conversion of humid primary forest to Acacia mangium plantations as well as agricultural use have been monitored since 1985 (Malmer 1992; Nykvist et al. 1996). After clear felling, the practice of intentional burning increased the concentration of ash and major nutrients in the adjacent streams, and high concentrations were detected in the baseflow even after 3 years (Malmer and Grip 1994; Malmer 1996; Table 5). The C:N ratio of organic matter in the stream water increased with burning (Malmer and Grip 1994), which suggests that more terrestrial organic matter was carried downstream as ash or black carbon than before burning (Bodí et al. 2014; Marques et al. 2017). Moreover, less vegetation due to burning would decrease the uptake and retention of $\mathrm{NO}_{3}{ }^{-}$in the soil and might increase $\mathrm{NO}_{3}{ }^{-}$leaching to downstream river waters (Rhoades et al. 2019). Ash and soil samples collected from burnt land showed that more $\mathrm{N}$ than $\mathrm{P}$ was lost during combustion (Kauffman et al. 1995, 1998; Murphy et al. 2006), suggesting that more $\mathrm{N}$ is leached than $P$ and that the N:P ratio increases in the downstream groundwater or river water after burning. The impact of burning on nutrient discharge would be mitigated by retention and uptake by riparian vegetation, indicating the importance of riparian management (Williams et al. 1997; Malmer 2004; de Souza et al. 2013).

In the tropical savanna of northern Australia (Kakadu National Park), fires in the late dry season caused high concentrations of total suspended solids (TSS), volatile suspended solids (VSS), N, and P in the adjacent stream after episodic storms and runoff, but fires in the early dry season did not have similar impacts (Townsend and Douglas 2000, 2004; Table 5). Because leaf litter and vegetation accumulate during the preceding wet season, ash and soil are retained by the litter, and nutrients are absorbed by the remaining vegetation in the early dry season (Townsend and Douglas 2004). Conversely, in the late dry season, a lower canopy cover and less vegetation and litter caused higher overland flows of ash and water, which increased the concentration of the abovementioned water quality variables in the stream (Townsend and Douglas 2000). These observations showed that the impacts of wildfire on the adjacent water properties are affected by the season of the fire and that forest management in the late dry season is especially important to prevent destructive wildfires and subsequent drastic changes in the downstream riverine and estuarine water properties.

The combustion of terrestrial biomass transports nutrients to adjacent rivers and the coastal sea through the atmosphere (i.e., dry and wet depositions). During extensive forest fires in Southeast Asia in 2006, N and P concentrations in both dry (aerosol) and wet (rainwater) depositions increased in Singapore (Sundarambal et al. 2010a). These depositions would considerably increase nutrient concentrations in coastal seawater and might increase the productivity of phytoplankton (Sundarambal et al. 2010b). Because the volatilization temperature of $\mathrm{N}$ is much lower than that of P (Bodí et al. 2014), more N would be lost during combustion, and the N:P ratio in atmospheric deposition is expected to decrease after fire events.

To summarize this section, the frequency and area of wildfires or intentional burning are increasing in tropical regions because of the conversion of primary forests to pasture and agricultural lands. Combustion changes the chemical compositions of terrestrial material and increases its mobility into adjacent streams and rivers. Because of the discharge of plant-derived materials and the

Table 5 A summary of the effects of wildfire or burning on the downstream riverine and estuarine water properties. The arrows before the water properties indicate that the subsequent water properties increased $(\uparrow)$, decreased $(\downarrow)$, or did not change $(\rightarrow)$. See the list of abbreviations for the water properties

\begin{tabular}{|c|c|c|}
\hline Study sites & $\begin{array}{l}\text { Effects on downstream water } \\
\text { properties }\end{array}$ & Sources \\
\hline \multirow[t]{2}{*}{ Mendolong catchment, Sabah, Malaysia } & $\uparrow: \mathrm{TN}, \mathrm{NO}_{3}{ }^{-}, \mathrm{NH}_{4}{ }^{+}, \mathrm{TP}, \mathrm{PO}_{4}{ }^{3-}, \mathrm{DOC}$ & $\begin{array}{l}\text { Grip et al. (1994), Malmer and Grip (1994), } \\
\text { Malmer (1996) }\end{array}$ \\
\hline & $\begin{array}{l}\uparrow: \mathrm{TN}^{\mathrm{NO}_{3}}{ }^{-}, \mathrm{NH}_{4}^{+} \\
\rightarrow: \mathrm{PO}_{4}{ }^{-}\end{array}$ & Malmer (2004) \\
\hline $\begin{array}{l}\text { Rain waters and aerosol deposition during smoke haze } \\
\text { events, Singapore }\end{array}$ & $\uparrow: \mathrm{TN}_{1} \mathrm{NO}_{3}^{-}+\mathrm{NO}_{2}^{-}, \mathrm{NH}_{4}^{+}, \mathrm{TP} \mathrm{PO}_{4}^{3-}$ & Sundarambal et al. $(2010 a, b)$ \\
\hline \multirow[t]{2}{*}{ Kakadu National Park catchments, Northern Territory, Australia } & $\uparrow: S S, T N, T P$ & Townsend and Douglas (2000) \\
\hline & $\begin{array}{l}\uparrow: T N \\
\rightarrow: S S, T P\end{array}$ & Townsend and Douglas (2004) \\
\hline
\end{tabular}


leaching of $\mathrm{N}$, the downstream river waters would have a higher $\mathrm{C}: \mathrm{N}$ ratio of organic matter and a higher $\mathrm{N}: \mathrm{P}$ ratio of dissolved inorganic nutrients than those before burning (Table 2). Tropical lands might lose organic matter and nutrients more quickly than other climate regions because of frequent heavy rainfall events in the tropics.

\section{Aquaculture}

Due to the global consumption of seafood, aquacultural production is currently almost equivalent to capture fisheries. Production from inland (land-based) aquaculture, where earthen ponds are created or culture tanks are placed on land, is almost twice as high as that from marine aquaculture and increased by 30\% from 2011 to 2016 worldwide (FAO 2018). Asia alone accounted for 93\% of global inland aquacultural production in 2016 (FAO 2018). Because aquaculture ponds are usually located beside coasts and estuaries to obtain and release water efficiently, mangroves and coastal forests are the major vegetation types that have been lost due to landbased aquaculture. On the coast of Hainan, China, 76\% of the mangrove loss was attributed to the creation of new aquaculture ponds (Herbeck et al., 2020). The difference in water properties between the influent and effluent through an aquaculture pond is considered a potential impact of this practice on the downstream environment.
Land-based aquaculture usually involves the feeding of organic pellets to raise target species as fast as possible (Rout and Bandyopadhyay 1999; Correia et al. 2014). However, a large part of the feed is not recovered as harvests but is wasted with the water discharged from the pond or accumulates in the sediment of the pond (Jackson et al. 2003; Islam et al. 2004; Anh et al. 2010). Therefore, most studies have shown that the effluent from aquaculture ponds tends to be eutrophic compared to the influent that enters the pond (Table 6). This eutrophication is largely composed of DOM and POM rather than dissolved inorganic nutrients such as $\mathrm{NH}_{4}{ }^{+}$ (Jackson et al. 2003; Costanzo et al. 2004; Islam et al. 2004; Molnar et al. 2013). For example, the total dissolved and particulate organic nitrogen (DON and PON, respectively) accounted for approximately $60-80 \%$ of the total $\mathrm{N}$ in the effluents from shrimp ponds in Queensland, Australia (Jackson et al. 2003; Costanzo et al. 2004); a value of $98 \%$ was reported for shrimp ponds along the west coast of New Caledonia (Thomas et al. 2010), and a value of $70 \%$ was reported for shrimp ponds in Hainan, China (Herbeck et al. 2013). These high percentages of organic $\mathrm{N}$ relative to inorganic $\mathrm{N}$ are most likely caused by extra feed pellets, feces excreted from cultured organisms, and/or the microbes that proliferate in the pond (Jackson et al. 2003; Thomas et al. 2010; Herbeck et al. 2013).

Laboratory experiments showed the release of $\mathrm{N}$ with different chemical forms specific to the source: while

Table 6 A summary of the effects of aquaculture on the downstream riverine and estuarine water properties. The arrows before the water properties indicate that the subsequent water properties increased $(\uparrow)$, decreased $(\downarrow)$, or did not change $(\rightarrow)$. See the list of abbreviations for the water properties

\begin{tabular}{|c|c|c|}
\hline Study sites & Effects on downstream water properties & Sources \\
\hline $\begin{array}{l}\text { Shrimp and fish ponds, Wenchang and Wenjiao Estuary, } \\
\text { Hainan, China }\end{array}$ & $\begin{array}{l}\uparrow: \mathrm{DOC}, \mathrm{DON}, \mathrm{DOC}: \mathrm{DON}, \mathrm{DIN}, \mathrm{NH}_{4}{ }^{+}, \mathrm{PO}_{4}{ }^{3-}, \\
\mathrm{Chl} a \\
\rightarrow: \mathrm{NO}_{3}{ }^{-}, \mathrm{NO}_{2}{ }^{-} \\
\downarrow: \mathrm{SS}_{\mathrm{POC}} \mathrm{PN}, \mathrm{POC}: \mathrm{PN}, \mathrm{DIN}: \mathrm{PO}_{4}{ }^{3-}\end{array}$ & $\begin{array}{l}\text { Herbeck et al. (2013), Herbeck et al } \\
\text { (2011) }\end{array}$ \\
\hline \multirow[t]{2}{*}{ Shrimp ponds, Can Gio, Vietnam } & $\begin{array}{l}\uparrow: \text { pH, POC, TN, DIN } \\
\downarrow: \text { SS, POC:PON }\end{array}$ & Vivier et al. (2019) \\
\hline & $\begin{array}{l}\uparrow: \mathrm{SS}_{1} \mathrm{pH}, \mathrm{TN}, \mathrm{TP}, \mathrm{BOD}, \mathrm{COD} \\
\rightarrow: \mathrm{DO}, \mathrm{NH}_{4}^{+}\end{array}$ & Anh et al. (2010) \\
\hline Shrimp ponds, the Bay of Bengal, Bangladesh & $\begin{array}{l}\uparrow: \mathrm{TN}^{\mathrm{NO}_{3}^{-}}, \mathrm{NO}_{2}^{-}, \mathrm{NH}_{4}^{+}, \mathrm{Chl} a \\
\rightarrow: \mathrm{DO}, \mathrm{pH}^{3} \\
\downarrow: \mathrm{SS}_{1} \mathrm{TP} \mathrm{PO}_{4}^{3-}\end{array}$ & Islam et al. (2004) \\
\hline \multirow[t]{2}{*}{ Shrimp ponds, Cardwell, Queensland, Australia } & $\uparrow: \mathrm{TN}, \mathrm{PON}, \mathrm{DON}, \mathrm{NH}_{4}^{+}, \mathrm{Chl} a$ & Jackson et al. (2003) \\
\hline & $\begin{array}{l}\uparrow: \mathrm{SS}_{,} \mathrm{TN}_{1} \mathrm{NO}_{3}^{-}, \mathrm{NH}_{4}^{+}, \mathrm{TP}, \mathrm{DIN}: \mathrm{DIP}, \mathrm{Chl} a \\
\rightarrow: \mathrm{PO}_{4}^{3-}\end{array}$ & Costanzo et al. (2004) \\
\hline Shrimp ponds, Saint Vincent Bay, New Caledonia & $\begin{array}{l}\uparrow: \mathrm{TN}_{1} \mathrm{PON}, \mathrm{DON}, \mathrm{TDN}, \mathrm{NH}_{4}^{+}, \mathrm{TP}, \mathrm{PP}, \mathrm{TDP}, \\
\mathrm{PO}_{4}{ }^{3-}\end{array}$ & Molnar et al. (2013) \\
\hline Shrimp ponds, Teremba Bay, Chambeyron Bay, New Caledonia & $\begin{array}{l}\uparrow: \text { SS, turbidity, POC, TN, PON, TP, Chl a } \\
\rightarrow: \text { DIN, DIP }\end{array}$ & Thomas et al. (2010) \\
\hline Fish and shrimp ponds, Hawaii, USA & $\begin{array}{l}\uparrow: \mathrm{SS}_{1} \text { turbidity, } \mathrm{TN}, \mathrm{NH}_{4}^{+}, \mathrm{TP}, \mathrm{Chl} a \\
\downarrow: \mathrm{NO}_{3}^{-}, \mathrm{NO}_{2}{ }^{-} \\
\uparrow \downarrow: \mathrm{PO}_{4}{ }^{3-}\end{array}$ & Ziemann et al. (1992) \\
\hline
\end{tabular}


cultured shrimp released a mixture of $\mathrm{NH}_{4}{ }^{+}$and DON (including urea), formulated feed pellets released more DON compounds than shrimp (Burford and Williams 2001). Because these pellet-derived DON compounds would be chemically more complex than urea (e.g., proteins and peptidoglycan remnants), the DON leached from feed pellets was less degradable for microbial communities in the water than shrimp-derived DON (mainly urea). These results suggest that when aquacultural wastewaters are discharged to adjacent rivers or estuaries, the impact of pellet-derived DON may be different from that of organism-derived DON and may reach farther downstream from the source (Thuy et al. 2011; Vivier et al. 2019).

Among inorganic $\mathrm{N}$ species in aquaculture ponds, $\mathrm{NH}_{4}{ }^{+}$usually constitutes the largest proportion, and $\mathrm{NO}_{3}{ }^{-}$and $\mathrm{NO}_{2}{ }^{-}$are much lower (Jackson et al. 2003; Costanzo et al. 2004; Thomas et al. 2010; Herbeck et al. 2013). $\mathrm{NH}_{4}{ }^{+}$is directly excreted from cultured organisms and is also produced through the degradation of labile DON, such as urea, contained in their feces (Ziemann et al. 1992; Burford and Williams 2001). Relatively low proportions of $\mathrm{NO}_{3}{ }^{-}$and $\mathrm{NO}_{2}{ }^{-}$in aquaculture ponds indicate that (1) $\mathrm{NH}_{4}{ }^{+}$is quickly absorbed by phytoplankton or discharged from the pond before nitrification proceeds (Jackson et al. 2003), (2) nitrification is not a major process of $\mathrm{N}$ transformation in aquaculture ponds because the process mainly occurs only at the aerobic sediment surface (Hargreaves 1998), and/or (3) even if $\mathrm{NO}_{3}{ }^{-}$is produced through nitrification, $\mathrm{NO}_{3}{ }^{-}$is again reduced through dissimilatory nitrate reduction into $\mathrm{NH}_{4}{ }^{+}$(DNRA) in anoxic pond sediment (Molnar et al. 2013). DNRA is generally enhanced by high temperature, high organic matter, and sulfate availability, all of which are likely to occur in the sediment of tropical aquaculture ponds in brackish and coastal areas (Christensen et al. 2003; Nizzoli et al. 2006; Dong et al. 2011). In fact, the proportion of DNRA to total $\mathrm{NO}_{3}{ }^{-}$reduction (DNRA + denitrification) increased in the sediment receiving effluents from shrimp ponds in New Caledonia, which resulted in a higher retention of $\mathrm{N}$ within the sediment due to the coupling of nitrification and $\mathrm{NO}_{3}{ }^{-}$reduction (Molnar et al. 2013).

It should be noted that the concentration of $\mathrm{NH}_{4}{ }^{+}$ often increased, but $\mathrm{PO}_{4}{ }^{3-}$ was relatively constant or even decreased in some aquaculture ponds, leading to elevated N:P ratios of dissolved inorganic nutrients in the pond water (Ziemann et al. 1992; Costanzo et al. 2004; Islam et al. 2004; Table 6). For example, the N:P ratio of dissolved inorganic nutrients increased from 14 (influent) to 214 (effluent) in shrimp ponds in Queensland, Australia (Costanzo et al. 2004). Increased N:P ratios would be caused by the retention of $\mathrm{P}$ in the pond sediment and microbes (Reddy et al. 1999). While $\mathrm{N}$ is relatively mobile and transformed by bacteria through nitrification or reduction (e.g., DNRA and denitrification), P needs to be stored in bacterial cells (e.g., nucleic acids and phospholipids) to maintain their basic cellular structures. In addition, inorganic $\mathrm{P}$ tends to be chemically bound with minerals such as $\mathrm{Ca}^{2+}$, and the formed particulate solids are deposited on the sediment under low water turbulence. These processes would lead to the accumulation of $\mathrm{P}$ in aquaculture pond sediments, gradually increasing the $\mathrm{N}: \mathrm{P}$ ratio of dissolved inorganic nutrients in the water column. In the sediment receiving aquacultural effluents in New Caledonia, the N:P ratio of dissolved inorganic nutrient fluxes from sediment to the overlying water was 42 , which was much higher than the $\mathrm{N}: \mathrm{P}$ ratio of organic matter fluxes (8.2), indicating that $\mathrm{PO}_{4}{ }^{3-}$ was retained in the sediment (Molnar et al. 2013). In downstream aquatic ecosystems receiving aquacultural effluents with high N:P ratios, the growth of phytoplankton might be limited by the availability of $\mathrm{P}$ (Costanzo et al. 2004).

However, even if $\mathrm{P}$ tends to be trapped in the pond compared to $\mathrm{N}$, this does not mean that aquacultural practices do not cause $\mathrm{P}$ enrichment in the downstream environment; providing feed pellets basically has the potential to increase the enrichment of both $\mathrm{N}$ and $\mathrm{P}$ (Ziemann et al. 1992; Herbeck et al. 2013; Molnar et al. 2013; Table 6). In fact, the water quality in aquaculture ponds is affected by many factors: the chemical composition and feeding amount of feed pellets (Rout and Bandyopadhyay 1999; Correia et al. 2014), the density and species of cultured organisms (Ziemann et al. 1992; Thomas et al. 2010), and the aeration and water residence time (exchange rate) in the pond (Hopkins et al. 1993; Martinez-Córdova et al., 1997). Modifications of aquacultural systems using microbial activities or engineering techniques to minimize environmental impacts have been reviewed in previous articles (Hargreaves 2006; Mook et al. 2012; van Rijn 2013; Martínez-Córdova et al. 2015; Li et al. 2020).

To summarize this section, a considerable portion of feed pellets may be discharged from aquaculture ponds as organic matter. While organism-derived urea is quickly decomposed, pellet-derived organic matter might be less degradable, and the impact of the effluent might reach far downstream from the aquaculture site. The discharge of $\mathrm{NH}_{4}{ }^{+}$derived from cultured organisms supplies another major impact on the downstream ecosystem because the nutrients contained in the freshwater provided from tropical primary forests are mainly $\mathrm{NO}_{3}{ }^{-}$. Because inland aquacultural practices are rapidly expanding in tropical regions, especially in Southeast Asia, these changes in aquatic processes will further increase in the future. 


\section{Urbanization}

With the increasing human population, tropical regions have urbanized faster than other climate regions (Montgomery 2008). Deforested tropical lands may be used for building private houses, commercial facilities, and industrial plants, where wastewaters are sometimes directly discharged into the adjacent environment without proper treatment. The chemical compositions of these wastewaters differ depending on the source, but various types of wastewaters from different sources are commonly mixed in urbanized rivers and estuaries (Davis and Koop 2006; Cunha et al. 2011; Fontana et al. 2014; Peyman et al. 2017). Even if wastewater is treated at a treatment plant, it is technically difficult to remove all dissolved inorganic nutrients from the water, which could cause eutrophication of the downstream aquatic ecosystem (Burford et al. 2012b). Other sources reviewed in the above sections, such as agricultural lands, may still affect urbanized areas through surface water runoff and/ or groundwater seepage if the source is located upstream.

The effects of urbanization on riverine and estuarine water quality have been studied at many sites in tropical regions (Table 7). Because these previous studies have already reported water quality variables such as nutrient concentration, this section mainly focuses on the characteristics of biogeochemical or microbial processes in tropical regions that could differ from those in cooler regions. Typically, the organic matter contained in eutrophic riverine or estuarine water is first decomposed by aerobic bacteria if DO is available, where nutrients such as $\mathrm{NH}_{4}{ }^{+}$are regenerated and DO is consumed (Pérez-Villalona et al. 2015). Because the temperature is usually higher in tropical regions than in other climate regions, bacterial respiration (DO consumption) and organic matter decomposition proceed more rapidly in tropical waters (Scofield et al. 2015; Follstad Shah et al. 2017). While DOM is mainly consumed in the water column, POM tends to sink down to the river or estuary floor and undergo decomposition at the bottom. The different patterns of water properties and biological activities with depth would be especially obvious in estuaries, where a halocline and stratification often occur (Martin et al. 2010; Shivaprasad et al. 2013). The tendencies toward stratification formation and DO depletion are highly dependent on the physical structure of the water path (e.g., depth, flow rate, and vertical mixing). A water body is easily stratified in a warm, deep, calm estuary, but not in a fast-flowing, shallow, upstream river. The degree of autotrophy or heterotrophy and the resulting $\mathrm{DO}$ concentration and $\mathrm{pCO}_{2}$ in the water are also controlled by these physical factors (Cotovicz Jr et al. 2015; Guenther et al. 2017; Santos and De Paula, 2019). Because nutrient-enriched wastewater is quickly flushed downstream in the latter case, eutrophication and subsequent algal blooms or hypoxia usually become apparent in the former case, where the residence time of water is sufficient (Perez et al. 2011; Romo et al. 2013; John et al. 2020).

Under hypoxic or anoxic conditions, anaerobic microbial processes such as denitrification become dominant. Because denitrification proceeds faster under warmer temperatures (e.g., 25-35 ${ }^{\circ} \mathrm{C}$; Myrstener et al. 2016; Meng et al. 2019), eutrophic tropical rivers and estuaries (especially sediment) experience active denitrification throughout the year. In an urbanized estuary in Puerto Rico, $21 \%$ of $\mathrm{N}$ was lost from the sediment through denitrification when organic matter was decomposed (Pérez-Villalona et al. 2015). However, denitrification might be gradually limited by the availability of $\mathrm{NO}_{3}{ }^{-}$ because the microbial production of $\mathrm{NO}_{3}{ }^{-}$(= nitrification) is expected to decrease under oxygen-depleted conditions (Koop-Jakobsen and Giblin 2010). Moreover, denitrification may be inhibited by sulfate-reducing bacteria because sulfide inhibits the final process of denitrification (Gardner and McCarthy 2009). This inhibition is likely to occur in the sediment of eutrophic estuaries because of the intrusion of seawater (Rysgaard et al. 1999).

Anammox (anaerobic ammonium oxidation) is another process that potentially removes $\mathrm{N}$ from aquatic ecosystems under oxygen-depleted conditions, where $\mathrm{NH}_{4}{ }^{+}$and $\mathrm{NO}_{2}{ }^{-}$are converted to $\mathrm{N}_{2}$. Because a high $\mathrm{NH}_{4}{ }^{+}$availability and DO depletion are basic requirements for anammox, eutrophic rivers and estuaries (especially sediment) are expected to be a hotspot of this bacterial activity (Liu et al. 2020). Moreover, most anammox bacteria prefer a warm temperature, which makes tropical aquatic environments further suitable for anammox to actively proceed (Tomaszewski et al. 2017). Although anammox was previously considered minor compared to denitrification, the recently revised isotope technique revealed that $64-86 \%$ of the total $\mathrm{N}$ loss in the seagrass sediment at Shaws Bay, Australia, was caused by anammox (Salk et al. 2017). A higher contribution of anammox than denitrification to the total $\mathrm{N}$ loss was also reported in the sediment from oyster farming in the Wallis Lake estuary, Australia (Erler et al. 2017), although the balance between anammox and denitrification is not consistent among studies (Dong et al. 2011; Jiao et al. 2018; Tan et al. 2019). The proportion of anammox and denitrification is affected by various environmental factors, such as DO and salinity (Jiang et al. 2017; Liu et al. 2020). Although relatively small contributions of microbial $\mathrm{N}$ removal through anammox and denitrification have been reported in cooler regions (Mulholland et al. 2009; Hellemann et al. 2017; Liu et al. 2020), the removal of $\mathrm{N}$ may be more significant in tropical environments because of the warmer temperature 
Table 7 A summary of the effects of urbanization on the downstream riverine and estuarine water properties. When most minerals (e.g., $\mathrm{Na}^{+}, \mathrm{Mg}^{2+}, \mathrm{Cl}^{-}, \mathrm{K}^{+}, \mathrm{Ca}^{2+}$ ) increased, they were collectively described as EC increased. The arrows before the water properties indicate that the subsequent water properties increased $(\uparrow)$, decreased $(\downarrow)$, or did not change $(\rightarrow)$. See the list of abbreviations for the water properties

\begin{tabular}{|c|c|c|}
\hline Study sites & Effects on downstream water properties & Sources \\
\hline Malacca river, Malacca, Malaysia & $\begin{array}{l}\uparrow: \text { EC, pH, SS, turbidity, BOD, COD } \\
\downarrow: \text { DO }\end{array}$ & Hua (2017) \\
\hline Penchala River, Selangor, Malaysia & $\begin{array}{l}\uparrow: \mathrm{EC}, \mathrm{NH}_{4}{ }^{+}, \mathrm{BOD}, \mathrm{COD} \\
\rightarrow: \mathrm{pH} \\
\downarrow: \mathrm{DO}\end{array}$ & Mahazar et al. (2013) \\
\hline Kuantan, Belat and Galing River, Malaysia & $\begin{array}{l}\uparrow: \mathrm{EC}, \mathrm{pH}, \mathrm{DIN}, \mathrm{NH}_{4}^{+}, \mathrm{TP}, \mathrm{COD} \\
\downarrow: \mathrm{DO}, \mathrm{NO}_{3}^{-}\end{array}$ & Kozaki et al. (2016) \\
\hline Day River, Red River Delta, Vietnam & $\begin{array}{l}\uparrow: \mathrm{TN} \mathrm{NH}_{4}{ }^{+}, \mathrm{TP}, \mathrm{PO}_{4}{ }^{3-}, \mathrm{Chl} a \\
\downarrow: \mathrm{TN}: \mathrm{TP}, \mathrm{DO}\end{array}$ & Hoang et al. (2018) \\
\hline Day River, Red River Delta, Vietnam & $\uparrow: \mathrm{DOC}, \mathrm{NH}_{4}^{+}, \mathrm{PO}_{4}^{3-}, \mathrm{pCO}_{2}, \mathrm{Chl} a$ & Duc et al. (2009) \\
\hline Saigon-Dongnai Rivers, Vietnam & $\uparrow: \mathrm{POC}^{\mathrm{TN}}, \mathrm{NH}_{4}^{+}, \mathrm{TP}, \mathrm{PO}_{4}{ }^{3-}, \mathrm{Chl} a$ & Nguyen et al. (2019b) \\
\hline Can Gio estuary, Vietnam & $\begin{array}{l}\uparrow: \mathrm{pCO}_{2} \\
\downarrow: \mathrm{DO}\end{array}$ & David et al. (2018) \\
\hline Can Tho, Mekong Delta, Vietnam & $\begin{array}{l}\uparrow: \text { Turbidity, } \mathrm{TN}^{-} \mathrm{NH}_{4}^{+}, \mathrm{PO}_{4}{ }^{3-}, \mathrm{COD} \\
\rightarrow: \mathrm{NO}_{3}^{-}, \mathrm{NO}_{2}^{-} \\
\downarrow: \mathrm{DO}\end{array}$ & Wilbers et al. (2014) \\
\hline Brantas River Basin, Java, Indonesia & $\uparrow: \mathrm{DON}, \mathrm{NO}_{3}^{-}, \mathrm{PO}_{4}^{3-}$ & Jennerjahn et al. (2004) \\
\hline Ciliwung watershed, Jakarta, Indonesia & $\begin{array}{l}\uparrow: T P, B O D, C O D \\
\downarrow: D O\end{array}$ & Permatasari et al. (2017) \\
\hline $\begin{array}{l}\text { Kholpetua-Arpangashia rivers, } \\
\text { Sundarbans, Bangladesh }\end{array}$ & $\begin{array}{l}\uparrow: \mathrm{NH}_{4}^{+}, \mathrm{PO}_{4}^{3-} \\
\rightarrow: \mathrm{NO}_{3}^{-} \\
\downarrow: \mathrm{DO}\end{array}$ & Rahaman et al. (2013) \\
\hline Manimala River, Kerala, India & $\begin{array}{l}\uparrow: \mathrm{EC}_{1} \mathrm{NO}_{3}^{-}, \mathrm{NO}_{2}^{-}, \mathrm{TP} \mathrm{PO}_{4}^{3-} \\
\downarrow: \mathrm{DO}\end{array}$ & Padmalal et al. (2012) \\
\hline Piracicaba River, São Paulo, Brazil & $\begin{array}{l}\uparrow: \mathrm{NH}_{4}^{+}, \mathrm{pCO}_{2} \\
\rightarrow: \mathrm{SS}_{1} \mathrm{NO}_{3}^{-} \\
\downarrow: \mathrm{DO}\end{array}$ & $\begin{array}{l}\text { Ballester et al. (1999) } \\
\text { Martinelli et al. (1999) }\end{array}$ \\
\hline Streams, São Paulo, Brazil & $\begin{array}{l}\uparrow: \mathrm{PO}_{4}^{3-} \\
\downarrow: \mathrm{DO}^{3-} \mathrm{NO}_{3}^{-}\end{array}$ & Silva et al. (2012) \\
\hline Streams, São Paulo, Brazil & $\uparrow: \mathrm{TN}, \mathrm{NH}_{4}^{+}, \mathrm{TP}, \mathrm{BOD}$ & Cunha et al. (2011) \\
\hline Monjolinho basin, São Carlos, Brazil & $\begin{array}{l}\uparrow: \mathrm{EC} \text {, turbidity, } \mathrm{TN} \mathrm{NO}_{3}{ }^{-}, \mathrm{TP}, \mathrm{PO}_{4}{ }^{3-}, \mathrm{BOD} \\
\downarrow: \mathrm{DO}\end{array}$ & Bere and Tundisi (2011) \\
\hline Guanabara Bay, Rio de Janeiro, Brazil & $\begin{array}{l}\uparrow: \mathrm{DO}_{,} \mathrm{NH}_{4}{ }^{+}, \mathrm{PO}_{4}{ }^{3-}, \mathrm{Chl} a \\
\downarrow: \mathrm{PCO}_{2}\end{array}$ & Cotovicz Jr et al. (2015) \\
\hline Streams, Rio de Janeiro, Brazil & $\begin{array}{l}\uparrow: \mathrm{TN}_{1} \mathrm{NH}_{4}^{+}, \mathrm{TP} \\
\downarrow: \mathrm{TN}: \mathrm{TP}\end{array}$ & Tromboni and Dodds (2017) \\
\hline Una River, São José da Vitória, Brazil & $\begin{array}{l}\uparrow: \mathrm{EC}, \mathrm{SS}, \text { turbidity, } \mathrm{PON}, \mathrm{DON}, \mathrm{NO}_{2}^{-}, \mathrm{NH}_{4}^{+}, \\
\mathrm{PP}, \mathrm{DOP}, \mathrm{PO}_{4}{ }^{3-} \\
\rightarrow: \mathrm{pH} \\
\downarrow: \mathrm{DO}\end{array}$ & Santos and De Paula (2019) \\
\hline Urban streams, Federal District, Brazil & $\begin{array}{l}\uparrow: \text { Turbidity, } \mathrm{DOC}, \mathrm{NO}_{3}{ }^{-}, \mathrm{NO}_{2}^{-}, \mathrm{NH}_{4}^{+} \\
\downarrow: \mathrm{DO}\end{array}$ & Silva et al. (2011) \\
\hline Cachoeira River estuary, Bahia, Brazil & $\begin{array}{l}\uparrow: \mathrm{NH}_{4}{ }^{+}, \mathrm{PO}_{4}{ }^{3-}, \mathrm{Chl} a \\
\downarrow: \mathrm{DO}, \mathrm{DIN}: \mathrm{DIP}\end{array}$ & Silva et al. (2013) \\
\hline Madeira River, Rondônia, Brazil & $\uparrow:$ TDN, TDP & Biggs et al. (2004) \\
\hline Streams, Puerto Rico & $\begin{array}{l}\uparrow: \text { Turbidity, TN, TP } \\
\downarrow: \text { DO }\end{array}$ & Uriarte et al. (2011) \\
\hline Streams, Mayagüez, Puerto Rico & $\begin{array}{l}\uparrow: E C \\
\downarrow: D O\end{array}$ & Wengrove and Ballestero (2012) \\
\hline Río Pedras Watershed, Puerto Rico & $\begin{array}{l}\uparrow: \mathrm{EC}, \mathrm{DOC}, \mathrm{DON}, \mathrm{NH}_{4}^{+}, \mathrm{PO}_{4}{ }^{3-} \\
\downarrow: \mathrm{DO}, \mathrm{NO}_{3}^{-}\end{array}$ & $\begin{array}{l}\text { De Jesús-Crespo and Ramírez (2011), Potter et al. (2013), } \\
\text { Ramírez et al. (2014) }\end{array}$ \\
\hline
\end{tabular}


(Pérez-Villalona et al. 2015). However, it should also be noted that $\mathrm{N}$ losses in the form of $\mathrm{N}_{2}$ (anammox and denitrification) are usually much lower than nutrient regeneration and would not considerably eliminate $\mathrm{N}$ from the aquatic ecosystem (Gardner and McCarthy 2009; Molnar et al. 2013; Erler et al. 2017; Salk et al. 2017; Domangue and Mortazavi 2018).

While $\mathrm{N}$ follows a pathway of release into the atmosphere through anammox or denitrification, $\mathrm{P}$ tends to remain in the aquatic system or to flow downstream by attaching to sediment particles, and this property of $\mathrm{P}$ sorption becomes stronger at higher temperatures (Zhang and Huang 2011; Nguyen et al. 2019a). This difference between $\mathrm{N}$ and $\mathrm{P}$ gradually lowers the N:P ratio in water or sediments in tropical estuaries (Cotovicz Jr et al. 2013). Therefore, the discharge of wastewater from urban areas would accelerate the decrease in the N:P ratio because (1) sewage itself generally has a low N:P ratio compared to freshwater from pristine forests, and (2) after organic matter is decomposed, eutrophic, oxygendepleted conditions potentially promote microbial $\mathrm{N}$ removal through anammox and denitrification (Sarma et al. 2009; Dong et al. 2011; Hoang et al. 2018; Tan et al. 2019). At the sites upstream of the Day River, Vietnam, much lower TN:TP ratios (a minimum of 2.9) than the Redfield ratio $(\mathrm{N}: \mathrm{P}=16)$ were measured and were attributed to sewage discharge, agricultural and industrial water runoff, and denitrification (Hoang et al. 2018). In addition, a low TN:TP ratio (10) was detected in the streams of the State of Rio de Janeiro, Brazil, which was considered to be due to the discharge of phosphate-based detergents from the ambient urbanized area (Tromboni and Dodds 2017). Although many pristine tropical rivers have high N:P ratios of dissolved inorganic nutrients, where primary production is limited by the availability of P (McDowell et al. 2019; Nguyen et al. 2019b), these impacts of urbanization might gradually shift the metabolic conditions to $\mathrm{N}$ limitation. The potential to decrease $\mathrm{N}: \mathrm{P}$ ratios with these microbial and chemical processes would be basically higher in tropical environments than in other climate regions due to the warmer temperature.

To summarize this section, urbanized rivers and estuaries that receive a variety of wastewaters typically have high concentrations of nutrients and minerals and low concentrations of DO (Table 2). The TN:TP ratio in the water would decrease with these eutrophication processes because excess $\mathrm{P}$ is often discharged as wastewater, and a portion of the $\mathrm{N}$ is lost from the aquatic ecosystem through anammox and denitrification under hypoxic or anoxic conditions. The decline in N:P ratios would be more severe in tropical regions than in other climate regions because $\mathrm{N}$ removal and $\mathrm{P}$ sorption processes are facilitated under warm temperature conditions.

\section{Conclusions and future research}

The present review shows that the impact of tropical land-use change on downstream rivers and estuaries is specific to the land use and human practices carried out on land, but overall, it appears that the impact is often more serious, and the biogeochemical processes are more enhanced in tropical regions than in temperate or cold regions. This difference derives mainly from the characteristics of the tropics: (1) tropical primary forests have a higher biomass and nutrient stocks supported by active photosynthesis and $\mathrm{N}$ fixation; (2) tropical regions have a higher precipitation, more frequent episodic flooding, and warmer temperatures; and (3) certain practices such as land-based aquaculture are rapidly expanding in tropical regions.

The actual impacts that downstream rivers and estuaries receive from changing land use depend on the intensity of each land-use effect; therefore, it is not easy to quantitatively evaluate the combined effects (Davis et al. 2016; Hapsari et al. 2020). For example, nutrient discharge may not enhance downstream primary production if sufficient light is not available for phytoplankton due to high precipitation and subsequent discharge of terrestrial soils (Burford et al. 2012a). The combined effects of land-use change and climate-related precipitation change should also be considered in the actual environment (Hapsari et al. 2020). Because these landuse changes are usually extensive, and nonpoint sources such as groundwater seepage also contribute to downstream water properties, it is challenging to understand the proportions of each land-use impact and their combination. The test of stable isotopes (e.g., $\delta^{13} \mathrm{C}$ and $\delta^{15} \mathrm{~N}$ ) might be a useful tool to identify the source and contribution of wastewater (Taillardat et al. 2020).

Impacts such as eutrophication or imbalanced nutrient supplies due to these tropical land-use changes would not recover quickly even if the cause was removed. A recent meta-analysis showed that terrestrial biogeochemical functions recovered more slowly after agricultural practices than after logging, most likely due to fertilizer use (Meli et al. 2017). Another meta-analysis on coastal ecosystem restoration projects showed that even 10 years after the reduction or cessation of anthropogenic nutrient inputs, the recovery completeness was only $24 \%$ of the original baseline condition (McCrackin et al. 2017). Because most of the data used for this analysis were from temperate climate regions such as Europe and North America, there may be some differences at tropical sites. For example, the high annual precipitation and occasional intensive rainfall in tropical regions would help eutrophic ecosystems flush away accumulated nutrients downstream. Additionally, if denitrification or anammox proceeds faster at warmer temperatures, $\mathrm{N}$ might be removed from the eutrophic 
site more quickly than in temperate cases. However, as it takes a longer time for tropical lands to recover their original biodiversity than temperate lands (Meli et al. 2017), the aquatic processes in the downstream river and estuary might also require a longer time for recovery in tropical regions. To evaluate recovery from eutrophication or disturbance of nutrient balance, long-term monitoring of more than 10 years is necessary, but such cases cannot be found in tropical regions at this time.

Another important aspect for future research is the change in elemental stoichiometry, such as the C:N:P ratio. Most previous studies have measured the concentration of target variables, but reports of the impact on element stoichiometry are relatively scarce. In temperate estuaries, primary production was expected to shift from $\mathrm{N}$ limitation to $\mathrm{P}$ limitation because of the increased inputs and retention of $\mathrm{N}$ (Howarth et al. 2011), although the limiting nutrients would be highly affected by regional factors. The present review has shown that the N: $P$ ratio in tropical estuaries may decline with changes in land use due to different loading and removal processes between $\mathrm{N}$ and $\mathrm{P}$. Additionally, the $\mathrm{C}: \mathrm{N}$ ratio of the available organic matter predominantly affects microbial processes of $\mathrm{N}$ transformation (e.g., DNRA, anammox, denitrification) (Erler et al. 2017). Thus, more research with accurate measurements of elemental ratios is needed to evaluate the ecological impacts of tropical land-use change on downstream aquatic processes.

\section{Abbreviations \\ BOD: Biological oxygen demand; Chl. a: Chlorophyll a; COD: Chemical oxygen demand; DIN: Dissolved inorganic nitrogen; DIP: Dissolved inorganic phosphorus; DOC: Dissolved organic carbon; DON: Dissolved organic nitrogen; DOP: Dissolved organic phosphorus; EC: Electrical conductivity; $\mathrm{OC}$ : Organic carbon; ON: Organic nitrogen; $\mathrm{pCO}_{2}$ : Partial pressure of $\mathrm{CO}_{2 i}$; POC: Particulate organic carbon; POM: Particulate organic matter; \\ PON: Particulate organic nitrogen; PP: Particulate phosphorus; SS: Suspended solids; TDN: Total dissolved nitrogen (= DON + DIN); TDP: Total dissolved phosphorus (= DOP + DIP); TN: Total nitrogen; TOC: Total organic carbon; TP: Total phosphorus}

\section{Acknowledgements}

We are grateful to two anonymous reviewers for providing many suggestions and recommendations to improve this article.

\section{Authors' contributions}

YT had a concept for this article; YT, EM, and WR performed the literature search and collection; YT drafted and revised the manuscript; All authors read and approved the final manuscript.

\section{Funding}

This study was financially supported by the research grants (No. CRGW G(013)/170601 and UBD/RSCH/URC/NIG/4.0/2020/001) funded by Universiti Brunei Darussalam.

\section{Availability of data and materials}

Not applicable

\section{Declarations}

Ethics approval and consent to participate Not applicable
Consent for publication

Not applicable

\section{Competing interests}

The authors declare that they have no competing interests.

Received: 29 January 2021 Accepted: 26 May 2021

Published online: 09 June 2021

\section{References}

Abril G, Martinez JM, Artigas LF, Moreira-Turca P, Benedetti MP, Vidal L, Meziane T, Kim JH, Bernardes MC, Savoye N, Deborde J, Souza EL, Albéric P, de Souza MFL, Roland F (2014) Amazon River carbon dioxide outgassing fuelled by wetlands. Nature 505(7483):395-398. https://doi.org/10.1038/nature12797

Achard F, Beuchle R, Mayaux P, Stibig HJ, Bodart C, Brink A, Carboni S, Desclée B, Donnay F, Eva HD, Lupi A, Raši R, Seliger R, Simonetti D (2014) Determination of tropical deforestation rates and related carbon losses from 1990 to 2010. Glob Chang Biol 20(8):2540-2554. https://doi.org/10.1111/gcb.12605

Adrianto HA, Spracklen DV, Arnold SR, Sitanggang IS, Syaufina L (2020) Forest and land fires are mainly associated with deforestation in Riau Province, Indonesia. Remote Sens 12(1):3. https://doi.org/10.3390/RS12010003

Ah Tung PG, Yusoff M, Majid NM, Joo GK, Huang GH (2009) Effect of N and K fertilizers on nutrient leaching and groundwater quality under mature oil palm in Sabah during the monsoon period. Am J Appl Sci 6(10):1788-1799. https://doi.org/10.3844/ajassp.2009.1788.1799

Anh PT, Kroeze C, Bush SR, Mol APJ (2010) Water pollution by intensive brackish shrimp farming in south-east Vietnam: causes and options for control. Agric Water Manag 97(6):872-882 https://doi.org/10.1016/j.agwat.2010.01.018

Argerich A, Johnson SL, Sebestyen SD, Rhoades CC, Greathouse E, Knoepp JD, Adams MB, Likens GE, Campbell JL, McDowell WH, Scatena FN, Ice GG (2013) Trends in stream nitrogen concentrations for forested reference catchments across the USA. Environ Res Lett 8(1):014039. https://doi.org/10.1088/17489326/8/1/014039

Arnuti F, Luiz LG, Pedro PA, Alves LA, Cecagno D, De Assis J, da S. Schaidhauer W, Anghinoni I, Chabbi A, de F. Carvalho PC (2020) Sheep dung composition and phosphorus and potassium release affected by grazing intensity and pasture development stage in an integrated crop-livestock system. Agronomy 10(8):1162. https://doi.org/10.3390/agronomy10081162

Assmann JM, Martins AP, Anghinoni I, de Oliveira Denardin LG, de Holanda Nichel G, de Andrade Costa SEVG, e Silva RAP, Balerini F, de Faccio Carvalho PC, Franzluebbers AJ (2017) Phosphorus and potassium cycling in a longterm no-till integrated soybean-beef cattle production system under different grazing intensities in subtropics. Nutr Cycl Agroecosyst 108(1):21-33. https://doi.org/10.1007/s10705-016-9818-6

Audry S, Akerman A, Riotte J, Oliva P, Maréchal JC, Fraysse F, Pokrovsky OS, Braun JJ (2014) Contribution of forest fire ash and plant litter decay on stream dissolved composition in a sub-humid tropical watershed (Mule Hole, Southern India). Chem Geol 372:144-161. https://doi.org/10.1016/j.chemgeo.2 014.02.016

Ballester MV, Martinelli LA, Krusche AV, Victoria RL, Bernardes M, Camargo PB (1999) Effects of increasing organic matter loading on the dissolved $\mathrm{O}_{2}$, free dissolved $\mathrm{CO}_{2}$ and respiration rates in the Piracicaba River basin, Southeast Brazil. Water Res 33(9):2119-2129. https://doi.org/10.1016/S0043-1354(98)0043 8-2

Banabas M, Scotter DR, Turner MA (2008) Losses of nitrogen fertiliser under oil palm in Papua New Guinea: 1. Water balance, and nitrogen in soil solution and runoff. Aust J Soil Res 46(4):340-347. https://doi.org/10.1071/SR07174

Bauer JE, Cai WJ, Raymond PA, Bianchi TS, Hopkinson CS, Regnier PAG (2013) The changing carbon cycle of the coastal ocean. Nature 504(7478):61-70. https:// doi.org/10.1038/nature12857

Bere T, Tundisi JG (2011) Influence of land use patterns on benthic diatoms communities and water quality in the tropical Monjolinho hydrological basin, S o Carlos-SP, Brazil. Water SA 37(1):93-102. https://doi.org/10.4314/wsa.v3 $7 \mathrm{i} 1.64112$

Biggs TW, Dunne T, Martinelli LA (2004) Natural controls and human impacts on stream nutrient concentrations in a deforested region of the Brazilian Amazon basin. Biogeochemistry 68(2):227-257. https://doi.org/10.1023/B: BIOG.0000025744.78309.2e

Bishop JM, Glenn CR, Amato DW, Dulai H (2017) Effect of land use and groundwater flow path on submarine groundwater discharge nutrient flux. J Hydrol Reg Stud 11:194-218. https://doi.org/10.1016/j.ejrh.2015.10.008 
Blanco AC, Nadaoka K, Yamamoto T, Kinjo K (2010) Dynamic evolution of nutrient discharge under stormflow and baseflow conditions in a coastal agricultural watershed in Ishigaki Island, Okinawa, Japan. Hydrol Process 24(18):2601-2616. https://doi.org/10.1002/hyp.7685

Bodí MB, Martin DA, Balfour VN, Santín C, Doerr SH, Pereira P, Cerdà A, MataixSolera J (2014) Wildland fire ash: production, composition and eco-hydrogeomorphic effects. Earth Sci Revs 130:103-127. https://doi.org/10.1016/j.ea rscirev.2013.12.007

Bramley RGV, Roth CH (2002) Land-use effects on water quality in an intensively managed catchment in the Australian humid tropics. Mar Freshw Res 53(5): 931-940. https://doi.org/10.1071/MF01242

Brodie JE, Mitchell AW (2005) Nutrients in Australian tropical rivers: changes with agricultural development and implications for receiving environments. Mar Freshw Res 56(3):279-302. https://doi.org/10.1071/MF04081

Brookshire ENJ, Hedin LO, Newbold JD, Sigman DM, Jackson JK (2012) Sustained losses of bioavailable nitrogen from montane tropical forests. Nat Geosci 5(2):123-126. https://doi.org/10.1038/ngeo1372

Brouwer LC, Riezebos HT (1998) Nutrient dynamics in intact and logged tropical rain forest in Guyana. In: Schulte A, Ruhiyat D (eds) Soils of Tropical Forest Ecosystems. Springer, Berlin, Heidelberg, pp 73-86. https://doi.org/10.1007/ 978-3-662-03649-5_7

Brown S, Lugo AE (1990) Effects of forest clearing and succession on the carbon and nitrogen content of soils in Puerto Rico and US Virgin Islands. Plant Soil 124(1):53-64. https://doi.org/10.1007/BF00010931

Burford MA, Revill AT, Smith J, Clementson L (2012b) Effect of sewage nutrients on algal production, biomass and pigments in tropical tidal creeks. Mar Pollut Bull 64(12):2671-2680. https://doi.org/10.1016/j.marpolbul.2012.10.008

Burford MA, Webster IT, Revill AT, Kenyon RA, Whittle M, Curwen G (2012a) Controls on phytoplankton productivity in a wet-dry tropical estuary. Estuar Coast Shelf Sci 113:141-151. https://doi.org/10.1016/j.ecss.2012.07.017

Burford MA, Williams KC (2001) The fate of nitrogenous waste from shrimp feeding. Aquaculture 198(1-2):79-93. https://doi.org/10.1016/S0044-84 86(00)00589-5

Camara M, Jamil NR, Abdullah AFB (2019) Impact of land uses on water quality in Malaysia: a review. Ecol Process 8:10. https://doi.org/10.1186/s13717-019-01 $64-x$

Cecil CB, Dulong FT, Harris RA, Cobb JC, Gluskoter HG, Nugroho H (2003) Observations on climate and sediment discharge in selected tropical rivers, Indonesia. In: Cecil CB, Edgar NT (eds) Climate Controls on Stratigraphy. SPEM Society for Sedimentary Geology, Tulsa, pp 29-50. https://doi.org/1 0.2110/pec.03.77.0029

Chappell NA, Douglas I, Hanapi JM, Tych W (2004) Sources of suspended sediment within a tropical catchment recovering from selective logging. Hydrol Process 18(4):685-701. https://doi.org/10.1002/hyp.1263

Chappell NA, Tych W, Yusop Z, Rahim NA, Kasran B (2005) Spatially significant effects of selective tropical forestry on water, nutrient and sediment flows: A modelling-supported review. In: Bonell M, Bruijnzeel LA (eds) Forests, Water and People in the Humid Tropics: Past. Present and Future Hydrological Research for Integrated Land and Water Management. Cambridge University Press, Cambridge, pp 513-532. https://doi.org/10.1017/CBO9780511535666.027

Chen CF, Son NT, Chang NB, Chen CR, Chang LY, Valdez M, Centeno G, Thompson CA, Aceituno JL (2013) Multi-decadal mangrove forest change detection and prediction in Honduras, Central America, with Landsat imagery and a Markov Chain Model. Remote Sens 5(12):6408-6426. https:// doi.org/10.3390/rs5126408

Chen D, Suter H, Islam A, Edis R, Freney JR, Walker CN (2008) Prospects of improving efficiency of fertiliser nitrogen in Australian agriculture: A review of enhanced efficiency fertilisers. Aust J Soil Res 46(4):289-301. https://doi. org/10.1071/SR07197

Christensen PB, Glud RN, Dalsgaard T, Gillespie P (2003) Impacts of longline mussel farming on oxygen and nitrogen dynamics and biological communities of coastal sediments. Aquaculture 218(1-4):567-588. https://doi. org/10.1016/S0044-8486(02)00587-2

Cleveland CC, Townsend AR, Schimel DS, Fisher H, Howarth RW, Hedin LO, Perakis SS, Latty EF, Von Fischer JC, Elseroad A, Wasson MF (1999) Global patterns of terrestrial biological nitrogen $\left(\mathrm{N}_{2}\right)$ fixation in natural ecosystems. Global Biogeochem Cycles 13(2):623-645. https://doi.org/10.1029/1 999GB900014

Cloern JE, Foster SQ, Kleckner AE (2014) Phytoplankton primary production in the world's estuarine-coastal ecosystems. Biogeosciences 11(9):2477-2501. https://doi.org/10.5194/bg-11-2477-2014
Comte I, Colin F, Grünberger O, Whalen JK, Harto Widodo R, Caliman JP (2015) Watershed-scale assessment of oil palm cultivation impact on water quality and nutrient fluxes: a case study in Sumatra (Indonesia). Environ Sci Pollut Res 22(10):7676-7695. https://doi.org/10.1007/s11356-015-4359-0

Comte I, Colin F, Whalen JK, Grünberger O, Caliman JP (2012) Agricultural practices in oil palm plantations and their impact on hydrological changes, nutrient fluxes and water quality in Indonesia. a review. Adv Agron 116:71124. https://doi.org/10.1016/B978-0-12-394277-7.00003-8

Correia ES, Wilkenfeld JS, Morris TC, Wei L, Prangnell DI, Samocha TM (2014) Intensive nursery production of the Pacific white shrimp Litopenaeus vannamei using two commercial feeds with high and low protein content in a biofloc-dominated system. Aquac Eng 59:48-54. https://doi.org/10.1016/j.a quaeng.2014.02.002

Costanzo SD, O'Donohue MJ, Dennison WC (2004) Assessing the influence and distribution of shrimp pond effluent in a tidal mangrove creek in north-east Australia. Mar Pollut Bull 48(5-6):514-525. https://doi.org/10.1016/j.ma rpolbul.2003.09.006

Cotovicz LC Jr, Knoppers BA, Brandini N, Costa Santos SJ, Abril G (2015) A strong $\mathrm{CO}_{2}$ sink enhanced by eutrophication in a tropical coastal embayment (Guanabara Bay, Rio de Janeiro, Brazil). Biogeosciences 12(20):6125-6146. https://doi.org/10.5194/bg-12-6125-2015

Cotovicz LC Jr, Machado EDC, Brandini N, Zem RC, Knoppers BA (2013) Distributions of total, inorganic and organic phosphorus in surface and recent sediments of the sub-tropical and semi-pristine Guaratuba Bay estuary, SE Brazil. Environ Earth Sci 72(2):373-386. https://doi.org/10.1007/s12 665-013-2958-y

Cunha DGF, Dodds WK, Carmo Calijuri MD (2011) Defining nutrient and biochemical oxygen demand baselines for tropical rivers and streams in São Paulo State (Brazil): A comparison between reference and impacted sites. Environ Manage 48(5):945-956. https://doi.org/10.1007/s00267-011-9739-8

Da Silva SS, Fearnside PM, Graça PMLA, Brown IF, Alencar A, Melo AWF (2018) Dynamics of forest fires in the southwestern Amazon. Forest Ecol Manag 424:312-322. https://doi.org/10.1016/j.foreco.2018.04.041

David F, Meziane T, Tran-Thi NT, Van VT, Thanh-Nho N, Taillardat P, Marchand C (2018) Carbon biogeochemistry and $\mathrm{CO}_{2}$ emissions in a human impacted and mangrove dominated tropical estuary (Can Gio, Vietnam). Biogeochemistry 138(3):261-275. https://doi.org/10.1007/s10533-018-0444-z

Davis AM, Pearson RG, Brodie JE, Butler B (2016) Review and conceptual models of agricultural impacts and water quality in waterways of the Great Barrier Reef catchment area. Mar Freshw Res 68(1):1-19. https://doi.org/10.1071/MF15301

Davis JR, Koop K (2006) Eutrophication in Australian rivers, reservoirs and estuaries - a southern hemisphere perspective on the science and its implications. Hydrobiologia 559(1):23-76. https://doi.org/10.1007/s10750005-4429-2

De Jesús-Crespo R, Ramírez A (2011) Effects of urbanization on stream physicochemistry and macroinvertebrate assemblages in a tropical urban watershed in Puerto Rico. J N Am Benthol Soc 30(3):739-750. https://doi. org/10.1899/10-081.1

De Jong EBP, Ragas AMJ, Nooteboom G, Mursidi M (2015) Changing water quality in the Middle Mahakam lakes: water quality trends in a context of rapid deforestation, mining and palm oil plantation development in Indonesia's Middle Mahakam Wetlands. Wetlands 35(4):733-744. https://doi. org/10.1007/s13157-015-0665-z

De Mello K, Taniwaki RH, de Paula FR, Valente RA, Randhir TO, Macedo DR, Leal CG, Rodrigues CB, Hughes RM (2020) Multiscale land use impacts on water quality: assessment, planning, and future perspectives in Brazil. J Environ Manage 270:110879. https://doi.org/10.1016/j.jenvman.2020.110879

De Mello K, Valente RA, Randhir TA, dos Santos ACA, Vettorazzi CA (2018b) Effects of land use and land cover on water quality of low-order streams in Southeastern Brazil: watershed versus riparian zone. Catena 167:130-138. https://doi.org/10.1016/j.catena.2018.04.027

De Mello K, Valente RA, Randhir TO, Vettorazzi CA (2018a) Impacts of tropical forest cover on water quality in agricultural watersheds in southeastern Brazil. Ecol Indic 93:1293-1301. https://doi.org/10.1016/j. ecolind.2018.06.030

De Souza ALTD, Fonseca DG, Libório RA, Tanaka MO (2013) Influence of riparian vegetation and forest structure on the water quality of rural low-order streams in SE Brazil. Forest Ecol Manag 298:12-18. https://doi.org/10.1016/j. foreco.2013.02.022

Deegan LA, Neill C, Haupert CL, Ballester MVR, Krusche AV, Victoria RL, Thomas SM, de Moor E (2011) Amazon deforestation alters small stream structure, 
nitrogen biogeochemistry and connectivity to larger rivers. Biogeochemistry 105(1-3):53-74. https://doi.org/10.1007/s10533-010-9540-4

Dessie A, Bredemeier M (2013) The effect of deforestation on water quality: a case study in Cienda Micro Watershed, Leyte, Philippines. Resour Environ 3(1):1-9. https://doi.org/10.5923/j.re.20130301.01

Ding W, Li S, He P, Huang S (2019) Contribution and fate of maize residue- ${ }^{15} \mathrm{~N}$ and urea- ${ }^{15} \mathrm{~N}$ as affected by $\mathrm{N}$ fertilization regime. PLoS One 14(1):e0210176. https://doi.org/10.1371/journal.pone.0210176

Dittmar T, de Rezende CE, Manecki M, Niggemann J, Ovalle ARC, Stubbins A, Bernardes MC (2012) Continuous flux of dissolved black carbon from a vanished tropical forest biome. Nat Geosci 5(9):618-622. https://doi.org/10.1 038/ngeo1541

Domangue RJ, Mortazavi B (2018) Nitrate reduction pathways in the presence of excess nitrogen in a shallow eutrophic estuary. Environ Pollut 238:599-606. https://doi.org/10.1016/j.envpol.2018.03.033

Don A, Schumacher J, Freibauer A (2011) Impact of tropical land-use change on soil organic carbon stocks - a meta-analysis. Glob Chang Biol 17(4):16581670. https://doi.org/10.1111/j.1365-2486.2010.02336.x

Dong LF, Sobey MN, Smith CJ, Rusmana I, Phillips W, Stott A, Osborn AM, Nedwell DB (2011) Dissimilatory reduction of nitrate to ammonium, not denitrification or anammox, dominates benthic nitrate reduction in tropical estuaries. Limnol Oceanogr 56(1):279-291. https://doi.org/10.4319/lo.2011. 56.1.0279

Douglas I, Spencer T, Greer T, Bidin K, Sinum W, Meng WW (1992) The impact of selective commercial logging on stream hydrology, chemistry and sediment loads in the Ulu Segama rain forest, Sabah, Malaysia. Philos Trans R Soc 335(1275):397-406. https://doi.org/10.1098/rstb.1992.0031

Downing JA, McClain M, Twilley R, Melack JM, Elser J, Rabalais NN, Lewis WM Jr, Turner RE, Corredor J, Soto D, Yanez-Arancibia A, Kopaska JA, Howarth RA (1999) The impact of accelerating land-use change on the N-cycle of tropical aquatic ecosystems: current conditions and projected changes. Biogeochemistry 46(1/3):109-148. https://doi.org/10.1023/A:1006156213761

Drake TW, Van Oost K, Barthel M, Bauters M, Hoyt AM, Podgorski DC, Six J, Boeckx P, Trumbore SE, Cizungu Ntaboba L, Spencer RGM (2019) Mobilization of aged and biolabile soil carbon by tropical deforestation. Nat Geosci 12(7):541-546. https://doi.org/10.1038/s41561-019-0384-9

Duc TA, Giang NH, Vachaud G, Choi SU (2009) Application of excess carbon dioxide partial pressure $\left(\mathrm{EpCO}_{2}\right)$ to the assessment of trophic state of surface water in the Red River delta of Vietnam. Int J Environ Stud 66(1):27-47. https://doi.org/10.1080/00207230902760473

Earl SR, Blinn DW (2003) Effects of wildfire ash on water chemistry and biota in south-western U.S.A. streams. Freshw Biol 48(6):1015-1030. https://doi.org/1 0.1046/j.1365-2427.2003.01066.x

Erb KH, Fetzel T, Plutzar C, Kastner T, Lauk C, Mayer A, Niedertscheider M, Körner C, Haberl H (2016) Biomass turnover time in terrestrial ecosystems halved by land use. Nat Geosci 9(9):674-681. https://doi.org/10.1038/ngeo2782

Erler DV, Welsh DT, Bennet WW, Meziane T, Hubas C, Nizzoli D, Ferguson AJP (2017) The impact of suspended oyster farming on nitrogen cycling and nitrous oxide production in a sub-tropical Australian estuary. Estuar Coast Shelf Sci 192:117-127. https://doi.org/10.1016/j.ecss.2017.05.007

Faithful J, Finlayson W (2005) Water quality assessment for sustainable agriculture in the Wet Tropics - a community-assisted approach. Mar Pollut Bull 51(1-4): 99-112. https://doi.org/10.1016/.jmarpolbul.2004.11.007

FAO (2018) The State of World Fisheries and Aquaculture 2018 - Meeting the sustainable development goals. Rome.

Feio MJ, Ferreira WR, Macedo DR, Eller AP, Alves CBM, França JS, Callisto M (2015) Defining and testing targets for the recovery of tropical streams based on macroinvertebrate communities and abiotic conditions. River Res Appl 31(1): 70-84. https://doi.org/10.1002/rra.2716

Figueiredo RO, Cak A, Markewitz D (2020) Agricultural impacts on hydrobiogeochemical cycling in the Amazon: is there any solution? Water 12(3):763. https://doi.org/10.3390/w12030763

Figueiredo RO, Markewitz D, Davidson EA, Schuler AE, Watrin OD, De Souza Silva P (2010) Land-use effects on the chemical attributes of low-order streams in the eastern Amazon. J Geophys Res-Biogeosci 115:G04004. https://doi.org/1 $0.1029 / 2009 J G 001200$

Follstad Shah JJ, Kominoski JS, Ardón M, Dodds WK, Gessner MO, Griffiths NA, Hawkins CP, Johnson SL, Lecerf A, LeRoy CJ, Manning DWP, Rosemond AD, Sinsabaugh RL, Swan CM, Webster JR, Zeglin LH (2017) Global synthesis of the temperature sensitivity of leaf litter breakdown in streams and rivers. Glob Change Biol 23(8):3064-3075. https://doi.org/10.1111/gcb.13609
Fontana L, Albuquerque ALS, Brenner M, Bonotto DM, Sabaris TPP, Pires MAF, Cotrim MEB, Bicudo DC (2014) The eutrophication history of a tropical water supply reservoir in Brazil. J Paleolimnol 51(1):29-43. https://doi.org/10.1007/s1 0933-013-9753-3

Friess DA, Rogers K, Lovelock CE, Krauss KW, Hamilton SE, Lee SY, Lucas R, Primavera J, Rajkaran A, Shi S (2019) The state of the world's mangrove forests: past, present, and future. Annu Rev Environ Resour 44(1):89-115. https://doi.org/10.1146/annurev-environ-101718-033302

Furnas M (2003) Catchments and corals: terrestrial runoff to the Great Barrier Reef. Australian Institute of Marine Science. Townsville, Queensland

Gandaseca S, Rosli N, Hanafi Idris M, Haruna Ahmed O, Pazi AMM (2015) Effects of converting tropical peat swamp forest into oil palm plantation on water quality. Am J Appl Sci 12(8):525-532. https://doi.org/10.3844/ajassp.2015.525. 532

Gardner WS, McCarthy MJ (2009) Nitrogen dynamics at the sediment-water interface in shallow, sub-tropical Florida Bay: why denitrification efficiency may decrease with increased eutrophication. Biogeochemistry 95(2):185-198. https://doi.org/10.1007/s10533-009-9329-5

Gibbs HK, Ruesch AS, Achard F, Clayton MK, Holmgren P, Ramankutty N, Foley JA (2010) Tropical forests were the primary sources of new agricultural land in the 1980s and 1990s. Proc Natl Acad Sci USA 107(38):16732-16737. https:// doi.org/10.1073/pnas.0910275107

Gomi T, Sidle RC, Noguchi S, Negishi JN, Nik AR, Sasaki S (2006) Sediment and wood accumulations in humid tropical headwater streams: effects of logging and riparian buffers. Forest Ecol Manag 224(1-2):166-175. https://doi.org/10.1 016/j.foreco.2005.12.016

Greer T, Sinun W, Douglas I, Bidin K (1996) Long term natural forest management and land-use change in a developing tropical catchment, Sabah, Malaysia. IAHS-AISH Publ 236:453-461

Grip H, Fritsch JM, Bruijnzeel (2005) Soil and water impacts during forest conversion and stabilisation to new land use. In: Bonell M, Bruijnzeel LAJ (eds) Forest, water and people in the humid tropics. Cambridge University Press, New York, pp 561-589. https://doi.org/10.1017/CBO9780511535666.029

Grip H, Malmer A, Wong F (1994) Converting tropical rain forest to forest plantation in sabah, malaysia. Part I. Dynamics and net losses of nutrients in control catchment streams. Hydrol Process 8(3):179-194. https://doi.org/10.1 002/hyp.3360080302

Guenther M, Araújo M, Noriega C, Flores-Montes M, Gonzalez-Rodriguez E, Neumann-Leitão S (2017) Plankton carbon metabolism and air-water $\mathrm{CO}_{2}$ fluxes at a hypereutrophic tropical estuary. Mar Ecol 38(2):1-12. https://doi. org/10.1111/maec.12423

Hapsari KA, Jennerjahn TC, Lukas MC, Karius V, Behling H (2020) Intertwined effects of climate and land use change on environmental dynamics and carbon accumulation in a mangrove-fringed coastal lagoon in Java, Indonesia. Glob Change Biol 26(3):1414-1431. https://doi.org/10.1111/gcb.14 926

Haraguchi A (2007) Effect of sulfuric acid discharge on river water chemistry in peat swamp forests in central Kalimantan, Indonesia. Limnology 8(2):175-182. https://doi.org/10.1007/s10201-007-0206-4

Hargreaves JA (1998) Nitrogen biogeochemistry of aquaculture ponds. Aquaculture 166(3-4):181-212. https://doi.org/10.1016/S0044-8486(98)002 98-1

Hargreaves JA (2006) Photosynthetic suspended-growth systems in aquaculture. Aquac Eng 34(3):344-363. https://doi.org/10.1016/j.aquaeng.2005.08.009

Hattori D, Kenzo T, Shirahama T, Harada Y, Kendawang JJ, Ninomiya I, Sakurai K (2019) Degradation of soil nutrients and slow recovery of biomass following shifting cultivation in the heath forests of Sarawak, Malaysia. For Ecol Manag 432:467-477. https://doi.org/10.1016/j.foreco.2018.09.051

Hedin LO, Brookshire ENJ, Menge DNL, Barron AR (2009) The nitrogen paradox in tropical forest ecosystems. Annu Rev Ecol Evol Syst 40:613-635. https://doi. org/10.1146/annurev.ecolsys.37.091305.110246

Hellemann D, Tallberg P, Bartl I, Voss M, Hietanen S (2017) Denitrification in an oligotrophic estuary: a delayed sink for riverine nitrate. Mar Ecol Prog Ser 583:63-80. https://doi.org/10.3354/meps12359

Herbeck LS, Krumme U, Andersen TJ, Jennerjahn TC (2020) Decadal trends in mangrove and pond aquaculture cover on Hainan (China) since 1966: mangrove loss, fragmentation and associated biogeochemical changes. Estuar Coast Shelf Sci 233:106531. https://doi.org/10.1016/j.ecss.2019.1 06531

Herbeck LS, Unger D, Krumme U, Liu SM, Jennerjahn TC (2011) Typhoon-induced precipitation impact on nutrient and suspended matter dynamics of a 
tropical estuary affected by human activities in Hainan, China. Estuar Coast Shelf Sci 93(4):375-388. https://doi.org/10.1016/j.ecss.2011.05.004

Herbeck LS, Unger D, Wu Y, Jennerjahn TC (2013) Effluent, nutrient and organic matter export from shrimp and fish ponds causing eutrophication in coastal and back-reef waters of NE hainan, tropical China. Cont Shelf Res 57:92-104. https://doi.org/10.1016/j.csr.2012.05.006

Ho J, Boughton EH, Jenkins DG, Sonnier G, Bohlen PJ, Chambers LG (2018) Ranching practices interactively affect soil nutrients in subtropical wetlands. Agric Ecosyst Environ 254:130-137. https://doi.org/10.1016/j.agee.2017.11.031

Hoang HTT, Duong TT, Nguyen KT, Le QTP, Luu MTN, Trinh DA, Le AH, Ho CT, Dang KD, Némery J, Orange D, Klein J (2018) Impact of anthropogenic activities on water quality and plankton communities in the Day River (Red River Delta, Vietnam). Environ Monit Assess 190(2):67. https://doi.org/10.1007/ s10661-017-6435-z

Hopkins JS, Hamilton RD, Sandier PA, Browdy CL, Stokes AD (1993) Effect of water exchange rate on production, water quality, effluent characteristics and nitrogen budgets of intensive shrimp ponds. J World Aquac Soc 24(3): 304-320. https://doi.org/10.1111/j.1749-7345.1993.tb00162.x

Howarth R, Chan F, Conley D, Garnier J, Doney SC, Marine R, Billen G (2011) Coupled biogeochemical cycles: eutrophication and hypoxia in temperate estuaries and coastal marine ecosystems. Front Ecol Environ 9(1):18-26. https://doi.org/10.1890/100008

Howarth RW, Billen G, Swaney D, Townsend A, Jaworski N, Lajtha K, Downing JA, Elmgren R, Caraco N, Jordan T, Berendse F, Freney J, Kudeyarov V, Murdoch $P$, Zhao-Liang Z (1996) Regional nitrogen budgets and riverine N \& P fluxes for the drainages to the North Atlantic Ocean: natural and human influences. Biogeochemistry 35(1):75-139. https://doi.org/10.1007/BF02179825

Hua AK (2017) Land use land cover changes in detection of water quality: a study based on remote sensing and multivariate statistics. J Environ Public Health 2017:5-7. https://doi.org/10.1155/2017/7515130

Ice GG, Neary DG, Adams PW (2004) Effects of wildfire on soils and watershed processes. J For 102(6):16-20. https://doi.org/10.1093/jof/102.6.16

Inoue M, Iwata T, Nakano S, Doi A, Miyasaka H (2003) Fish assemblage composition, abundance-habitat relationships and habitat use in tropical rain forest streams, Sarawak, Borneo: effects of past deforestation. Biosph Conserv 5(2):71-86 doi: 10.20798/biospherecons.5.2 71

Islam MS, Sarker MJ, Yamamoto T, Wahab MA, Tanaka M (2004) Water and sediment quality, partial mass budget and effluent $\mathrm{N}$ loading in coastal brackishwater shrimp farms in Bangladesh. Mar Pollut Bull 48(5-6):471-485. https://doi.org/10.1016/j.marpolbul.2003.08.025

Iwata T, Nakano S, Inoue M (2003) Impacts of past riparian deforestation on stream communities in a tropical rain forest in Borneo. Ecol Appl 13(2):461473 https://doi.org/10.1890/1051-0761(2003)013[0461:IOPRDO]2.0.CO;2

Jackson C, Preston N, Thompson PJ, Burford M (2003) Nitrogen budget and effluent nitrogen components at an intensive shrimp farm. Aquaculture 218(1-4):397-411. https://doi.org/10.1016/S0044-8486(03)00014-0

Jeffrey LC, Maher DT, Santos IR, McMahon A, Tait DR (2016) Groundwater, acid and carbon dioxide dynamics along a coastal wetland, lake and estuary continuum. Estuaries Coasts 39(5):1325-1344. https://doi.org/10.1007/s12237016-0099-8

Jennerjahn TC, Ittekkot V, Klöpper S, Adi S, Purwo Nugroho S, Sudiana N, Yusmal A, Prihartanto G-HB (2004) Biogeochemistry of a tropical river affected by human activities in its catchment: Brantas River estuary and coastal waters of Madura Strait, Java, Indonesia. Estuar Coast Shelf Sci 60(3):503-514. https:// doi.org/10.1016/j.ecss.2004.02.008

Jennerjahn TC, Soman K, Ittekkot V, Nordhaus I, Sooraj S, Priya RS, Lahajnar N (2008) Effect of land use on the biogeochemistry of dissolved nutrients and suspended and sedimentary organic matter in the tropical Kallada River and Ashtamudi estuary, Kerela, India. Biogeochemistry 90(1):29-47. https://doi. org/10.1007/s10533-008-9228-1

Jiang X, Hou L, Zheng Y, Liu M, Yin G, Gao J, Li X, Wang R, Yu C, Lin X (2017) Salinity-driven shifts in the activity, diversity, and abundance of anammox bacteria of estuarine and coastal wetlands. Phys Chem Earth 97:46-53. https://doi.org/10.1016/j.pce.2017.01.012

Jiao L, Wu J, He X, Wen X, Li Y, Hong Y (2018) Significant microbial nitrogen loss from denitrification and anammox in the land-sea interface of low permeable sediments. Int Biodeterior Biodegrad 135:80-89. https://doi.org/1 0.1016/j.ibiod.2018.10.002

Jobbágy EG, Jackson RB (2000) The vertical distribution of soil organic carbon and its relation to climate and vegetation. Ecol Appl 10(2):423-436. https:// doi.org/10.2307/2641104
John S, Muraleedharan KR, Revichandran C, Azeez SA, Seena G, Cazenave PW (2020) What controls the flushing efficiency and particle transport pathways in a tropical Estuary? Cochin Estuary, Southwest coast of India. Water 12(3): 908. https://doi.org/10.3390/w12030908

Kauffman JB, Cummings DL, Ward DE (1998) Fire in the Brazilian Amazon: 2. Biomass, nutrient pools and losses in cattle pastures. Oecologia 113(3):415427. https://doi.org/10.1007/s004420050394

Kauffman JB, Cummings DL, Ward DE, Babbitt R (1995) Fire in the Brazilian Amazon: 1. Biomass, nutrient pools, and losses in slashed primary forests. Oecologia 104(4):397-408. https://doi.org/10.1007/BF00341336

Koop-Jakobsen K, Giblin AE (2010) The effect of increased nitrate loading on nitrate reduction via denitrification and DNRA in salt marsh sediments. Limnol Oceanogr 55(2):789-802. https://doi.org/10.4319/lo.2010.55.2.0789

Kozaki D, Rahim MHA, Wan Ishak MF, Yusoff MM, Mori M, Nakatani N, Tanaka K (2016) Assessment of the river water pollution levels in Kuantan, Malaysia, using ion-exclusion chromatographic data, water quality indices, and land usage patterns. Air Soil Water Res 9:1-11. https://doi.org/10.4137/ASWR.S3301 7

Li Z, Yu E, Zhang K, Gong W, Xia Y, Tian J, Wang G, Xie J (2020) Water treatment effect, microbial community structure, and metabolic characteristics in a field-scale aquaculture wastewater treatment system. Front Microbiol 11:930. https://doi.org/10.3389/fmicb.2020.00930

Lin P, Chen M, Guo L (2012) Speciation and transformation of phosphorus and its mixing behavior in the Bay of St. Louis estuary in the northern Gulf of Mexico. Geochim Cosmochim Acta 87:283-298. https://doi.org/10.1016/j. gca.2012.03.040

Ling TY, Soo CL, Liew JJ, Nyanti L, Sim SF, Grinang J (2017) Application of multivariate statistical analysis in evaluation of surface river water quality of a tropical river. J Chem 2017:5737452-5737413. https://doi.org/10.1155/2017/ 5737452

Ling TY, Soo CL, Sivalingam JR, Nyanti L, Sim SF, Grinang J (2016) Assessment of the water and sediment quality of tropical forest streams in upper reaches of the Baleh River, Sarawak, Malaysia, subjected to logging activities. J Chem 2016:8503931-8503913. https://doi.org/10.1155/2016/ 8503931

Liu C, Hou L, Liu M, Zheng Y, Yin G, Dong H, Liang X, Li X, Gao D, Zhang Z (2020) In situ nitrogen removal processes in intertidal wetlands of the Yangtze Estuary. J Environ Sci 93:91-97. https://doi.org/10.1016/j.jes.2020.03. 005

López-Poma R, Pivello VR, de Brito GS, Bautista S (2020) Impact of the conversion of Brazilian woodland savanna (cerradão) to pasture and Eucalyptus plantations on soil nitrogen mineralization. Sci Total Environ 704:135397. https://doi.org/10.1016/j.scitotenv.2019.135397

Lorion CM, Kennedy BP (2009) Riparian forest buffers mitigate the effects of deforestation on fish assemblages in tropical headwater streams. Ecol Appl 19(2):468-479. https://doi.org/10.1890/08-0050.1

Mahazar A, Othman MS, Kutty AA, Desa MNM (2013) Monitoring urban river water quality using macroinvertebrate and physico-chemical parameters: case study of Penchala river, Malaysia. J Biol Sci 13(6):474-482. https://doi. org/10.3923/jbs.2013.474.482

Maia AG, Schons SZ (2020) The effect of environmental change on out-migration in the Brazilian Amazon rainforest. Popul Environ 42(2):183-218. https://doi. org/10.1007/s11111-020-00358-2

Malmer A (1992) Water-yield changes after clear-felling tropical rainforest and establishment of forest plantation in Sabah, Malaysia. J Hydrol 134(1-4):77-94. https://doi.org/10.1016/0022-1694(92)90029-U

Malmer A (1996) Hydrological effects and nutrient losses of forest plantation establishment on tropical rainforest land in Sabah, Malaysia. J Hydrol 174(12):129-148. https://doi.org/10.1016/0022-1694(95)02757-2

Malmer A (2004) Streamwater quality as affected by wild fires in natural and manmade vegetation in Malaysian Borneo. Hydrol Process 18(5):853-864 https://doi.org/10.1002/hyp.1255

Malmer A, Grip H (1994) Converting tropical rainforest to forest plantation in Sabah, Malaysia. Part II. Effects on nutrient dynamics and net losses in streamwater. Hydrol Process 8(3):195-209. https://doi.org/10.1002/hyp.33 60080303

Maranguit D, Guillaume T, Kuzyakov Y (2017) Land-use change affects phosphorus fractions in highly weathered tropical soils. Catena 149(1):385393. https://doi.org/10.1016/j.catena.2016.10.010

Marques JSJ, Dittmar T, Niggemann J, Almeida MG, Gomez-Saez GV, Rezende CE (2017) Dissolved black carbon in the headwaters-to-ocean continuum of 
Paraiba do Sul River, Brazil. Front Earth Sci 5:1-12. https://doi.org/10.3389/fea rt.2017.00011

Marryanna L, Siti Aisah S, Saiful Iskandar K (2007) Water quality response to clear felling trees for forest plantation establishment at Bukit Tarek F.R., Selangor. J Phys Sci 18(1):33-45

Martin GD, Muraleedharan KR, Vijay JG, Rejomon G, Madhu NV, Shivaprasad A, Haridevi CK, Nair M, Balachandran KK, Revichandran C, Jayalakshmy KV Chandramohanakumar N (2010) Formation of anoxia and denitrification in the bottom waters of a tropical estuary, southwest coast of India. Biogeosciences Discuss 7(2):1751-1782. https://doi.org/10.5194/bgd-7-1751-2 010

Martinelli LA, Krusche AV, Victoria RL, Camargo PB, Bernardes M, Ferraz ES, Moraes JM, Ballester VM (1999) Effect of sewage on the chemical composition of Piracicaba River, Brazil. Water Air Soil Pollut 110(9):67-79. https://doi.org/10.1023/A:1005052213652

Martínez-Córdova LR, Emerenciano M, Miranda-Baeza A, Martínez-Porchas M (2015) Microbial-based systems for aquaculture of fish and shrimp: an updated review. Rev Aquac 7(2):131-148. https://doi.org/10.1111/raq.12058

Martinez-Córdova LR, Villarreal-Colmenares H, Porchas-Cornejo MA, NaranjoParamo J, Aragon-Noriega A (1997) Effect of aeration rate on growth, survival and yield of white shrimp Penaeus vannamei in low water exchange ponds. Aquac Eng 16(1-2):85-90. https://doi.org/10.1016/50144-8609(96)01010-2

McCrackin ML, Jones HP, Jones PC, Moreno-Mateos D (2017) Recovery of lakes and coastal marine ecosystems from eutrophication: a global meta-analysis. Limnol Oceanogr 62(2):507-518. https://doi.org/10.1002/Ino.10441

McCulloch M, Fallon S, Wyndham T, Hendy E, Lough J, Barnes D (2003) Coral record of increased sediment flux to the inner Great Barrier Reef since European settlement. Nature 421(6924):727-730. https://doi.org/10.1038/na ture01361

McDowell WH (1998) Internal nutrient fluxes in a Puerto Rican rain forest. J Trop Ecol 14(4):521-536. https://doi.org/10.1017/S0266467498000376

McDowell WH, Lugo AE, James A (1995) Export of nutrients and major ions from Caribbean catchments. J N Am Bentol Soc 14(1):12-20. https://doi.org/10.23 07/1467721

McDowell WH, McDowell WG, Potter JD, Ramírez A (2019) Nutrient export and elemental stoichiometry in an urban tropical river. Ecol Appl 29(2):e01839. https://doi.org/10.1002/eap.1839

Meli P. Holl KD, Rey Benayas JM, Jones HP, Jones PC, Montoya D, Mateos DM (2017) A global review of past land use, climate, and active vs. passive restoration effects on forest recovery. PLoS ONE 12(2):e0171368. https://doi. org/10.1371/journal.pone.0171368

Melling L, Hatano R, Kah JG (2005) Methane fluxes from three ecosystems in tropical peatland of Sarawak, Malaysia. Soil Biol Biochem 37(8):1445-1453. https://doi.org/10.1016/.soilbio.2005.01.001

Meng J, Li J, Li J, Nan J, Deng K, Antwi P (2019) Effect of temperature on nitrogen removal and biological mechanism in an up-flow microaerobic sludge reactor treating wastewater rich in ammonium and lack in carbon source. Chemosphere 216:186-194. https://doi.org/10.1016/j.chemosphere.2 018.10 .132

Miettinen J, Shi C, Liew SC (2011) Deforestation rates in insular Southeast Asia between 2000 and 2010. Glob Chang Biol 17(7):2261-2270. https://doi.org/1 0.1111/j.1365-2486.2011.02398.x

Mitchell A, Reghenzani J, Faithful J, Furnas M, Brodie J (2009) Relationships between land use and nutrient concentrations in streams draining a 'wettropics' catchment in northern Australia. Mar Freshw Res 60(11):1097-1108. https://doi.org/10.1071/MF08330

Mitchell AW, Bramley RGV, Johnson AKL (1997) Export of nutrients and suspended sediment during a cyclone-mediated flood event in the Herbert River catchment, Australia. Mar Freshw Res 48(1):79-88. https://doi.org/10.1 071/MF96021

Mitchell AW, Reghenzani JR, Furnas MJ (2001) Nitrogen levels in the Tully River A long-term view. Water Sci Technol 43(9):99-105. https://doi.org/10.2166/ wst.2001.0516

Miyajima T, Tsuboi Y, Tanaka Y, Koike I (2009) Export of inorganic carbon from two Southeast Asian mangrove forests to adjacent estuaries as estimated by the stable isotope composition of dissolved inorganic carbon. J Geophys Res 114(G1):G01024. https://doi.org/10.1029/2008JG000861

Molnar N, Welsh DT, Marchand C, Deborde J, Meziane T (2013) Impacts of shrimp farm effluent on water quality, benthic metabolism and $\mathrm{N}$-dynamics in a mangrove forest (New Caledonia). Estuar Coast Shelf Sci 117(2):12-21. https://doi.org/10.1016/j.ecss.2012.07.012
Mook WT, Chakrabarti MH, Aroua MK, Khan GMA, Ali BS, Islam MS, Abu Hassan MA (2012) Removal of total ammonia nitrogen (TAN), nitrate and total organic carbon (TOC) from aquaculture wastewater using electrochemical technology: a review. Desalination 285:1-13. https://doi.org/10.1016/.desal.2 011.09 .029

Mulholland PJ, Hall ROJ, Sobota DJ, Dodds WK, Findlay SEG, Grimm NB, Hamilton SK, McDowell WH, O'Brien JM, Tank JL, Ashkenas LR, Cooper LW, Dahm CN, Gregory SV, Johnson SL, Meyer UL, Peterson BJ, Poole GC, Valett HM, Webster JR, Arango CP, Beaulieu JJ, Bernot MJ, Burgin AJ, Crenshaw CL, Helton AM, Johnson LT, Niederlehner BR, Potter JD, Sheibley RW, Thomas, S. M. (2009). Nitrate removal in stream ecosystems measured by ${ }^{15} \mathrm{~N}$ addition experiments: denitrification. Limnol Oceanogr 54(3):666-680. doi: https://doi. org/10.4319/lo.2009.54.3.0666

Müller-Dum D, Warneke T, Rixen T, Müller M, Baum A, Christodoulou A, Oakes J, Eyre BD, Notholt J (2019) Impact of peatlands on carbon dioxide $\left(\mathrm{CO}_{2}\right)$ emissions from the Rajang River and Estuary, Malaysia. Biogeosciences 16(1): 17-32. https://doi.org/10.5194/bg-16-17-2019

Murphy JD, Johnson DW, Miller WW, Walker RF, Carroll EF, Blank RR (2006) Wildfire effects on soil nutrients and leaching in a Tahoe Basin watershed. J Environ Qual 35(2):479-489. https://doi.org/10.2134/jeq2005.0144

Myrstener $\mathrm{M}$, Jonsson A, Bergström AK (2016) The effects of temperature and resource availability on denitrification and relative $\mathrm{N}_{2} \mathrm{O}$ production in boreal lake sediments. J Environ Sci 47:82-90. https://doi.org/10.1016/j.jes.2016.03. 003

Nainar A, Bidin K, Walsh RPD, Ewers RM, Reynolds G (2017) Effects of different land-use on suspended sediment dynamics in Sabah (Malaysian borneo) - a view at the event and annual timescales. Hydrol Res Lett 11(1):79-84. https:// doi.org/10.3178/HRL.11.79

Neill C, Deegan LA, Thomas SM, Cerri CC (2001) Deforestation for pasture alters nitrogen and phosphorus in small Amazonian streams. Ecol Appl 11(6):18171828. https://doi.org/10.1890/1051-0761(2001)011[1817:DFPANA]2.0.CO;2

Neill C, Deegan LA, Thomas SM, Haupert CL, Krusche AV, Ballester VM, Victoria RL (2006) Deforestation alters the hydraulic and biogeochemical characteristics of small lowland Amazonian streams. Hydrol Process 20(12):2563-2580. https://doi.org/10.1002/hyp.6216

Neill C, Jankowski K, Brando PM, Coe MT, Deegan LA, Macedo MN, Riskin SH, Porder S, Elsenbeer H, Krusche AV (2017) Surprisingly modest water quality impacts from expansion and intensification of large-scale commercial agriculture in the Brazilian Amazon-Cerrado Region. Trop Conserv Sci 10:1-5. https://doi.org/10.1177/1940082917720669

Nguyen TTN, Némery J, Gratiot N, Garnier J, Strady E, Tran VQ, Nguyen AT, Nguyen TNT, Golliet C, Aimé J (2019a) Phosphorus adsorption/desorption processes in the tropical Saigon River estuary (Southern Vietnam) impacted by a megacity. Estuar Coast Shelf Sci 227:106321. https://doi.org/10.1016/j. ecss.2019.106321

Nguyen TTN, Némery J, Gratiot N, Strady E, Tran VQ, Nguyen AT, Aimé J, Peyne A (2019b) Nutrient dynamics and eutrophication assessment in the tropical river system of Saigon - Dongnai (southern Vietnam). Sci Total Environ 653: 370-383. https://doi.org/10.1016/j.scitotenv.2018.10.319

Nieminen M, Sallantaus T, Ukonmaanaho L, Nieminen TM, Sarkkola S (2017) Nitrogen and phosphorus concentrations in discharge from drained peatland forests are increasing. Sci Total Environ 609:974-981. https://doi.org/10.1016/j. scitotenv.2017.07.210

Nik AR, Harding D (1992) The effects of selective logging methods on water yield and streamflow parameters in Peninsular Malaysia. J Trop For Sci 5(2):130154

Nizzoli D, Welsh DT, Fano EA, Viaroli P (2006) Impact of clam and mussel farming on benthic metabolism and nitrogen cycling, with emphasis on nitrate reduction pathways. Mar Ecol Prog Ser 315:151-165. https://doi.org/10.3354/ meps315151

Nóbrega RLB, Guzha AC, Lamparter G, Amorim RSS, Couto EG, Hughes HJ, Jungkunst HF, Gerold G (2018) Impacts of land-use and land-cover change on stream hydrochemistry in the Cerrado and Amazon biomes. Sci Total Environ 635:259-274. https://doi.org/10.1016/.jscitotenv.2018.03.356

Noriega C, Araujo M (2014) Carbon dioxide emissions from estuaries of northern and northeastern Brazil. Sci Rep 4(1):6164. https://doi.org/10.1038/srep06164

Nykvist N, Liang SB, Malmer A (1996) Effects of tractor logging and burning on biomass production and nutrient accumulation in Acacia mangium plantation in Sabah, Malaysia. J Trop For Sci 9(2):161-183

OECD/FAO (2017) OECD-FAO Agricultural Outlook 2017-2026. OECD Publishing, Paris. https://doi.org/10.1787/agr_outlook-2017-en 
OECD/FAO (2019) Latin American agriculture: prospects and challenges. In: OECD-FAO Agricultural Outlook 2019-2028. OECD Publishing, Paris. https:// doi.org/10.1787/b2b742eb-en

Oehler T, Eiche E, Putra D, Adyasari D, Hennig H, Mallast U, Moosdorf N (2018) Seasonal variability of land-ocean groundwater nutrient fluxes from a tropical karstic region (southern Java, Indonesia). J Hydrol 565:662-671. https://doi. org/10.1016/j.jhydrol.2018.08.077

Padmalal D, Remya SI, Jyothi SJ, Baijulal B, Babu KN, Baiju RS (2012) Water quality and dissolved inorganic fluxes of N, P, SO4, and $\mathrm{K}$ of a small catchment river in the Southwestern Coast of India. Environ Monit Assess 184(3):1541-1557. https://doi.org/10.1007/s10661-011-2059-x

Peel M, Finlayson B, McMahon T (2007) Updated world map of the KöppenGeiger climate classification. Hydrol Earth Syst Sci 11(5):1633-2007. https:// doi.org/10.5194/hess-11-1633-2007

Perez BC, Day JW, Justic D, Lane RR, Twilley RR (2011) Nutrient stoichiometry, freshwater residence time, and nutrient retention in a river-dominated estuary in the Mississippi delta. Hydrobiologia 658(1):41-54. https://doi.org/1 0.1007/s10750-010-0472-8

Pérez-Villalona H, Cornwell JC, Ortiz-Zayas JR, Cuevas E (2015) Sediment denitrification and nutrient fluxes in the San José Lagoon, a tropical Lagoon in the highly urbanized San Juan Bay Estuary, Puerto Rico. Estuaries Coasts 38(6):2259-2278. https://doi.org/10.1007/s12237-015-9953-3

Permatasari PA, Setiawan Y, Khairiah RN, Effendi H (2017) The effect of land use change on water quality: a case study in Ciliwung Watershed. IOP Conf Ser Earth Environ Sci 54:012026. https://doi.org/10.1088/1742-6596/755/1/011001

Peyman N, Travakloy Sany SB, Tajfard M, Hashim R, Rezayi M, Karlen DJ (2017) The status and characteristics of eutrophication in tropical coastal water. Environ Sci Process Impacts 19(8):1086-1103. https://doi.org/10.1039/ c7em00200a

Potter JD, McDowell WH, Helton AM, Daley ML (2013) Incorporating urban infrastructure into biogeochemical assessment of urban tropical streams in Puerto Rico. Biogeochemistry 121(1):271-286. https://doi.org/10.1007/s10533013-9914-5

Prasertsak P, Freney JR, Denmead OT, Saffigna PG, Prove BG, Reghenzani JR (2002) Effect of fertilizer placement on nitrogen loss from sugarcane in tropical Queensland. Nutr Cycl Agroecosyst 62(3):229-239. https://doi.org/1 0.1023/A:1021279309222

Rahaman SMB, Sarder L, Rahaman MS, Ghosh AK, Biswas SK, Siraj SMS, Huq KA, Hasanuzzaman AFM, Islam SS (2013) Nutrient dynamics in the Sundarbans mangrove estuarine system of Bangladesh under different weather and tidal cycles. Ecol Process 2:29. https://doi.org/10.1186/2192-1709-2-29

Ramírez A, Rosas KG, Lugo AE, Ramos-González OM (2014) Spatio-temporal variation in stream water chemistry in a tropical urban watershed. Ecol Soc 19(2):45

Recha JW, Lehmann J, Todd Walter M, Pell A, Verchot L, Johnson M (2012) Stream discharge in tropical headwater catchments as a result of forest clearing and soil degradation. Earth Interact 16(13):1-18. https://doi.org/10.11 75/2012El000439.1

Reddy CS, Bird NG, Sreelakshmi S, Manikandan TM, Asra M, Krishna PH, Jha CS, Rao PVN, Diwakar PG (2019) Identification and characterization of spatiotemporal hotspots of forest fires in South Asia. Environ Monit Assess 191(Suppl 3):791. https://doi.org/10.1007/s10661-019-7695-6

Reddy KR, Kadlec RH, Flaig E, Gale PM (1999) Phosphorus retention in streams and wetlands: a review. Crit Rev Environ Sci Technol 29(1):83-146. https://doi. org/10.1080/10643389991259182

Rhoades CC, Chow AT, Covino TP, Fegel TS, Pierson DN, Rhea AE (2019) The legacy of a severe wildfire on stream nitrogen and carbon in headwater catchments. Ecosystems 22(3):643-657. https://doi.org/10.1007/s10021-018-02 93-6

Richards DR, Friess DA (2016) Rates and drivers of mangrove deforestation in Southeast Asia, 2000-2012. Proc Natl Acad Sci USA 113(2):344-349. https:// doi.org/10.1073/pnas.1510272113

Ríos-Villamizar EA, Piedade MTF, Junk WJ, Waichman AV (2017) Surface water quality and deforestation of the Purus river basin, Brazilian Amazon. Int Aquat Res 9(1):81-88. https://doi.org/10.1007/s40071-016-0150-1

Riskin SH, Neill C, Jankowski K, Krusche AV, McHorney R, Elsenbeer H, Macedo MN, Nunes D, Porder S (2017) Solute and sediment export from Amazon forest and soybean headwater streams. Ecol Appl 27(1):193207. https://doi.org/10.1002/eap.1428

Rivett MO, Buss SR, Morgan P, Smith JWN, Bemment CD (2008) Nitrate attenuation in groundwater: a review of biogeochemical controlling processes. Water Res 42(16):4215-4232. https://doi.org/10.1016/j.watres.2008. 07.020

Rocha KF, Mariano E, Grassmann CS, Trivelin PCO, Rosolem CA (2019) Fate of ${ }^{15} \mathrm{~N}$ fertilizer applied to maize in rotation with tropical forage grasses. Field Crops Res 238:35-44. https://doi.org/10.1016/j.fcr.2019.04.018

Romo S, Soria J, Fernández F, Ouahid Y, Barón-Solá Á (2013) Water residence time and the dynamics of toxic cyanobacteria. Freshw Biol 58(3):513-522. https://doi.org/10.1111/j.1365-2427.2012.02734.x

Rosa IMD, Smith MJ, Weam OR, Purves D, Ewers RM (2016) The environmental legacy of modern tropical deforestation. Curr Biol 26(16):2161-2166. https:// doi.org/10.1016/j.cub.2016.06.013

Rosli N, Gandaseca S, Gerusu GJ, Heng RKJ, Ahmed OH, Idris MH, Mohamad Pazi AM (2020) Quality of tropical river water in different catchments of canopy cover. Malaysian For 83(1):128-148

Rout RK, Bandyopadhyay S (1999) A comparative study of shrimp feed pellets processed through cooking extruder and meat mincer. Aquac Eng 19(2):7179. https://doi.org/10.1016/S0144-8609(98)00034-X

Rust AJ, Hogue TS, Saxe S, McCray J (2018) Post-fire water-quality response in the western United States. Int J Wildland Fire 27(3):203-216. https://doi.org/10.1 071/WF17115

Rysgaard S, Thastum P, Dalsgaard T, Christensen PB, Sloth NP (1999) Effects of salinity on $\mathrm{NH}_{4}{ }^{+}$adsorption capacity, nitrification, and denitrification in Danish estuarine sediments. Estuaries 22(1):21-30. https://doi.org/10.23 07/1352923

Salk KR, Erler DV, Eyre BD, Carlson-Perret N, Ostrom NE (2017) Unexpectedly high degree of anammox and DNRA in seagrass sediments: description and application of a revised isotope pairing technique. Geochim Cosmochim Acta 211:64-78. https://doi.org/10.1016/j.gca.2017.05.012

Sammut J, White I, Melville MD (1996) Acidification of an estuarine tributary in eastern Australia due to drainage of acid sulfate soils. Mar Freshw Res 47(5): 669-684. https://doi.org/10.1071/MF9960669

Sanderson PG, Taylor DM (2003) Short-term water quality variability in two tropical estuaries, central Sumatra. Estuaries 26(1):156-165. https://doi.org/1 $0.1007 / B F 02691702$

Santos DA, De Paula FCF (2019) Diel changes in aquatic biogeochemistry of a pristine stream receiving untreated urban sewage at Brazilian rainforest. Environ Sci Pollut Res 26(12):12324-12334. https://doi.org/10.1007/s11356-01 9-04386-W

Sarma WSS, Gupta SNM, Babu PVR, Acharya T, Harikrishnachari N, Vishnuvardhan K, Rao NS, Reddy NPC, Sarma W, Sadhuram Y, Murty TVR, Kumar MD (2009) Influence of river discharge on plankton metabolic rates in the tropical monsoon driven Godavari estuary, India. Estuar Coast Shelf Sci 85(4):515-524. https://doi.org/10.1016/j.ecss.2009.09.003

Sarma WSS, Kumar NA, Prasad VR, Venkataramana V, Appalanaidu S, Sridevi B, Kumar BSK, Bharati MD, Subbaiah CV, Acharyya T, Rao GD, Viswanadham R, Gawade L, Manjary DT, Kumar PP, Rajeev K, NPC R, Sarma W, Kumar MD, Sadhuram Y, TVR M (2011) High $\mathrm{CO}_{2}$ emissions from the tropical Godavari estuary (India) associated with monsoon river discharges. Geophys Res Lett 38(8):L08601. https://doi.org/10.1029/2011 GL046928

Scofield V, Jacques SMS, Guimarães JRD, Farjalla VF (2015) Potential changes in bacterial metabolism associated with increased water temperature and nutrient inputs in tropical humic lagoons. Front Microbiol 6:310. https://doi. org/10.3389/fmicb.2015.00310

Sebilo M, Mayer B, Nicolardot B, Pinay G, Mariotti A (2013) Long-term fate of nitrate fertilizer in agricultural soils. Proc Natl Acad Sci USA 110(45):1818518189. https://doi.org/10.1073/pnas.1305372110

Shivaprasad A, Vinita J, Revichandran C, Reny PD, Deepak MP, Muraleedharan KR, Kumar KRN (2013) Seasonal stratification and property distributions in a tropical estuary (Cochin estuary, west coast, India). Hydrol Earth Syst Sci 17(1): 187-199. https://doi.org/10.5194/hess-17-187-2013

Sileshi GW, Nhamo N, Mafongoya PL, Tanimu J (2017) Stoichiometry of animal manure and implications for nutrient cycling and agriculture in sub-Saharan Africa. Nutr Cycl Agroecosyst 107(1):91-105. https://doi.org/10.1007/s10705016-9817-7

Silva DML, Camargo PB, McDowell WH, Vieira I, Salomão MSMB, Martinelli LA (2012) Influence of land use changes on water chemistry in streams in the state of São Paulo, southeast Brazil. An Acad Bras Cienc 84(4):919-930. https://doi.org/10.1590/S0001-37652012000400007

Silva JSO, da Bustamante MMC, Markewitz D, Krusche AV, Ferreira LG (2011) Effects of land cover on chemical characteristics of streams in the Cerrado 
region of Brazil. Biogeochemistry 105(1):75-88. https://doi.org/10.1007/s1 0533-010-9557-8

Silva MAMÊ, Eça GF, Santos DF, Guimarães AG, Lima MC, de Souza MFL (2013) Dissolved inorganic nutrients and chlorophyll a in an estuary receiving sewage treatment plant effluents: Cachoeira River estuary (NE Brazil). Environ Monit Assess 185(7):5387-5399. https://doi.org/10.1007/s10661-012-2953-x

Smith HG, Sheridan GJ, Lane PNJ, Nyman P, Haydon S (2011) Wildfire effects on water quality in forest catchments: a review with implications for water supply. J Hydrol 396(1-2):170-192. https://doi.org/10.1016/j.jhydrol.2010.10. 043

Statham PJ (2012) Nutrients in estuaries - An overview and the potential impacts of climate change. Sci Total Environ 434:213-227

Sundarambal P, Balasubramanian R, Tkalich P, He J (2010a) Impact of biomass burning on ocean water quality in Southeast Asia through atmospheric deposition: field observations. Atmos Chem Phys 10(23):11323-11336. https://doi.org/10.5194/acp-10-11323-2010

Sundarambal P, Tkalich P, Balasubramanian R (2010b) Impact of biomass burning on ocean water quality in Southeast Asia through atmospheric deposition: eutrophication modeling. Atmos Chem Phys 10(23):11337-11357. https://doi. org/10.5194/acp-10-11337-2010

Suryatmojo H, Fujimoto M, Kosugi K, Mizuyama T (2014) Runoff and soil erosion characteristics in different periods of an intensive forest management system in a tropical Indonesian rainforest. Int J Sustain Dev Plan 9(6):830-846. https://doi.org/10.2495/SDP-V9-N6-830-846

Tacconi L (2016) Preventing fires and haze in Southeast Asia. Nat Clim Change 6(7):640-643. https://doi.org/10.1038/nclimate3008

Tahiru AA, Doke DA, Baatuuwie BN (2020) Effect of land use and land cover changes on water quality in the Nawuni Catchment of the White Volta Basin, Northern Region, Ghana. Appl Water Sci 10(8):1-14. https://doi.org/10.1007/ s13201-020-01272-6

Taillardat P, Marchand C, Friess DA, Widory D, David F, Ohte N, Nakamura T, Vinh TV, Thanh-Nho N, Ziegler AD (2020) Respective contribution of urban wastewater and mangroves on nutrient dynamics in a tropical estuary during the monsoon season. Mar Pollut Bull 160:111652. https://doi.org/10.1 016/j.marpolbul.2020.111652

Tan E, Zou W, Jiang X, Wan X, Hsu TC, Zheng Z, Chen L, Xu M, Dai M, Kao SJ (2019) Organic matter decomposition sustains sedimentary nitrogen loss in the Pearl River Estuary, China. Sci Total Environ 648:508-517. https://doi.org/1 0.1016/j.scitotenv.2018.08.109

Taniwaki RH, Cassiano CC, Filoso S, de Barros Ferraz SF, de Camargo PB, Martinelli LA (2017) Impacts of converting low-intensity pastureland to high-intensity bioenergy cropland on the water quality of tropical streams in Brazil. Sci Total Environ 584-585:339-347. https://doi.org/10.1016/j.scitotenv.2016.12.1 50

Thomas SM, Neill C, Deegan LA, Krusche AV, Ballester VM, Victoria RL (2004) Influences of land use and stream size on particulate and dissolved materials in a small Amazonian stream network. Biogeochemistry 68(2):135-151. https://doi.org/10.1023/B:BIOG.0000025734.66083.b7

Thomas Y, Courties C, El Helwe Y, Herbland A, Lemonnier H (2010) Spatial and temporal extension of eutrophication associated with shrimp farm wastewater discharges in the New Caledonia lagoon. Mar Pollut Bull 61(712):387-398. https://doi.org/10.1016/j.marpolbul.2010.07.005

Thomaz EL, Nunes DD, Watanabe M (2020) Effects of tropical forest conversion on soil and aquatic systems in southwestern Brazilian Amazonia: a synthesis. Environ Res 183:109220. https://doi.org/10.1016/j.envres.2020.109220

Thorburn PJ, Biggs JS, Weier KL, Keating BA (2003) Nitrate in groundwaters of intensive agricultural areas in coastal Northeastern Australia. Agric Ecosyst Environ 94(1):49-58. https://doi.org/10.1016/50167-8809(02)00018-X

Thuy HTT, Nga LP, Loan TTC (2011) Antibiotic contaminants in coastal wetlands from Vietnamese shrimp farming. Environ Sci Pollut Res 18(6):835-841. https://doi.org/10.1007/s11356-011-0475-7

Tomaszewski M, Cema G, Ziembińska-Buczyńska A (2017) Influence of temperature and $\mathrm{pH}$ on the anammox process: a review and meta-analysis. Chemosphere 182:203-214. https://doi.org/10.1016/j.chemosphere.2017.05. 003

Townsend SA, Douglas MM (2000) The effect of three fire regimes on stream water quality, water yield and export coefficients in a tropical savanna (northern Australia). J Hydrol 229(3-4):118-137. https://doi.org/10.1016/ S0022-1694(00)00165-7

Townsend SA, Douglas MM (2004) The effect of a wildfire on stream water quality and catchment water yield in a tropical savanna excluded from fire for 10 years (Kakadu National Park, North Australia). Water Res 38(13):30513058. https://doi.org/10.1016/j.watres.2004.04.009

Tromboni F, Dodds WK (2017) Relationships between land use and stream nutrient concentrations in a highly urbanized tropical region of Brazil: thresholds and riparian zones. Environ Manage 60(1):30-40. https://doi.org/1 0.1007/s00267-017-0858-8

Uriarte M, Yackulic CB, Lim Y, Arce-Nazario JA (2011) Influence of land use on water quality in a tropical landscape: a multi-scale analysis. Landsc Ecol 26(8): 1151-1164. https://doi.org/10.1007/s10980-011-9642-y

Valiela I, Barth-Jensen C, Stone T, Crusius J, Fox S, Bartholomew M (2013) Deforestation of watersheds of Panama: nutrient retention and export to streams. Biogeochemistry 115(1-3):299-315. https://doi.org/10.1007/s10533013-9836-2

Valiela I, Bartholomew M, Giblin A, Tucker J, Harris C, Martinetto P, Otter M, Camili L, Stone T (2014) Watershed deforestation and down-estuary transformations alter sources, transport, and export of suspended particles in Panamanian mangrove estuaries. Ecosystems 17(1):96-111. https://doi.org/10.1007/s10021013-9709-5

Valiela I, Bowen JL, York JK (2001) Mangrove forests: one of the world's threatened major tropical environments. BioScience 51(10):807-815 https:// doi.org/10.1641/0006-3568(2001)051[0807:MFOOTW]2.0.CO;2

Van Ha NT, Takizawa S, Oguma K, Van Phuoc N (2011) Sources and leaching of manganese and iron in the Saigon River Basin, Vietnam. Water Sci Technol 63(10):2231-2237. https://doi.org/10.2166/wst.2011.460

Van Rijn J (2013) Waste treatment in recirculating aquaculture systems. Aquac Eng 53:49-56. https://doi.org/10.1016/j.aquaeng.2012.11.010

Vivier B, David F, Marchand C, Thanh-Nho N, Meziane T (2019) Fatty acids, C and $\mathrm{N}$ dynamics and stable isotope ratios during experimental degradation of shrimp pond effluents in mangrove water. Mar Environ Res 150:104751. https://doi.org/10.1016/.marenvres.2019.104751

Vuai SA, Nakamura K, Tokuyama A (2003) Geochemical characteristics of runoff from acid sulfate soils in the northern area of Okinawa Island, Japan. Geochem J 37(5):579-592. https://doi.org/10.2343/geochemj.37.579

Ward ND, Krusche AV, Sawakuchi HO, Brito DC, Cunha AC, Moura JMS, da Silva R, Yager PL, Keil RG, Richey JE (2015) The compositional evolution of dissolved and particulate organic matter along the lower Amazon River-Óbidos to the ocean. Mar Chem 177:244-256. https://doi.org/10.1016/j.marchem.2015.06. 013

Wengrove ME, Ballestero TP (2012) Upstream to downstream: stormwater quality in Mayagüez, Puerto Rico. Environ Monit Assess 184(8):5025-5034. https://doi. org/10.1007/s10661-011-2318-x

Wetterstedt JÅM, Persson T, Ågren Gl (2010) Temperature sensitivity and substrate quality in soil organic matter decomposition: results of an incubation study with three substrates. Glob Chang Biol 16(6):1806-1819. https://doi.org/10.1111/j.1365-2486.2009.02112.x

Wilbers GJ, Becker M, Nga LT, Sebesvari Z, Renaud FG (2014) Spatial and temporal variability of surface water pollution in the Mekong Delta, Vietnam. Sci Total Environ 485-486:653-665. https://doi.org/10.1016/j.scitotenv.2014.03. 049

Williams MR, Fisher TR, Melack JM (1997) Solute dynamics in soil water and groundwater in a central Amazon catchment undergoing deforestation. Biogeochemistry 38(3):303-335. https://doi.org/10.1023/A:1005801303639

Williams MR, King KW (2020) Changing rainfall patterns over the Western Lake Erie Basin (1975-2017): effects on tributary discharge and phosphorus load. Water Resour Res 56(3):e2019WR025985. https://doi.org/10.1029/2019WR02 5985

Zhang JZ, Huang XL (2011) Effect of temperature and salinity on phosphate sorption on marine sediments. Environ Sci Technol 45(16):6831-6837. https:// doi.org/10.1021/es200867p

Zhang Q, Tao Z, Ma Z, Gao Q, Deng H, Xu P, Ding J, Wang Z, Lin Y (2019) Hydroecological controls on riverine organic carbon dynamics in the tropical monsoon region. Sci Rep 9(1):11871. https://doi.org/10.1038/s41598-019-482 08-y

Ziemann DA, Walsh WA, Saphore EG, Fulton-Bennett K (1992) A survey of water quality characteristics of effluent from Hawaiian aquaculture facilities. J World Aquac Soc 23(3):180-191. https://doi.org/10.1111/j.17497345.1992.tb00767.x

\section{Publisher's Note}

Springer Nature remains neutral with regard to jurisdictional claims in published maps and institutional affiliations. 